\title{
Long-term observations of tropospheric particle number size distributions and equivalent black carbon mass concentrations in the German Ultrafine Aerosol Network (GUAN)
}

\author{
Wolfram Birmili ${ }^{1, a}$, Kay Weinhold ${ }^{1}$, Fabian Rasch ${ }^{1}$, André Sonntag ${ }^{1}$, Jia Sun ${ }^{1}$, Maik Merkel ${ }^{1}$, \\ Alfred Wiedensohler ${ }^{1}$, Susanne Bastian ${ }^{2}$, Alexander Schladitz ${ }^{2, b}$, Gunter Löschau ${ }^{2}$, Josef Cyrys ${ }^{3,4}$, \\ Mike Pitz $^{3, c}$, Jianwei Gu ${ }^{3,4}$, Thomas Kusch ${ }^{3,4}$, Harald Flentje ${ }^{5}$, Ulrich Quass ${ }^{6}$, Heinz Kaminski ${ }^{6}$, \\ Thomas A. J. Kuhlbusch ${ }^{6, \mathrm{~d}}$, Frank Meinhardt ${ }^{7}$, Andreas Schwerin ${ }^{7}$, Olaf Bath ${ }^{7}$, Ludwig Ries ${ }^{7}$, \\ Holger Gerwig ${ }^{7}$, Klaus Wirtz ${ }^{7}$, and Markus Fiebig ${ }^{8}$ \\ ${ }^{1}$ Leibniz Institute for Tropospheric Research (TROPOS), Leipzig, Germany \\ ${ }^{2}$ Saxon State Office for Environment, Agriculture and Geology (LfULG), Dresden, Germany \\ ${ }^{3}$ Helmholtz Zentrum Munich (HMGU), Institute of Epidemiology II, Neuherberg, Germany \\ ${ }^{4}$ University of Augsburg (UA), Wissenschaftszentrum Umwelt, Augsburg, Germany \\ ${ }^{5}$ Deutscher Wetterdienst (DWD), Meteorologisches Observatorium Hohenpeißenberg, \\ Hohenpeißenberg, Germany \\ ${ }^{6}$ Institute of Energy and Environmental Technology (IUTA), Duisburg, Germany \\ ${ }^{7}$ German Federal Environment Agency (UBA), Dessau-Rosslau, Germany \\ ${ }^{8}$ Norwegian Institute for Air Research (NILU), Kjeller, Norway \\ ${ }^{a}$ now at: German Federal Environment Agency (UBA), Berlin, Germany \\ ${ }^{b}$ now at: SICK Engineering GmbH, Ottendorf-Okrilla, Germany \\ ${ }^{c}$ now at: Bavarian Environment Agency (LUA), Augsburg, Germany \\ ${ }^{d}$ now at: Federal Institute for Occupational Safety and Health (BAuA), Dortmund, Germany
}

Correspondence to: Wolfram Birmili (wolfram.birmili@uba.de)

Received: 23 October 2015 - Published in Earth Syst. Sci. Data Discuss.: 24 November 2015

Revised: 11 July 2016 - Accepted: 9 August 2016 - Published: 26 August 2016

\begin{abstract}
The German Ultrafine Aerosol Network (GUAN) is a cooperative atmospheric observation network, which aims at improving the scientific understanding of aerosol-related effects in the troposphere. The network addresses research questions dedicated to both climate- and health-related effects. GUAN's core activity has been the continuous collection of tropospheric particle number size distributions and black carbon mass concentrations at 17 observation sites in Germany. These sites cover various environmental settings including urban traffic, urban background, rural background, and Alpine mountains. In association with partner projects, GUAN has implemented a high degree of harmonisation of instrumentation, operating procedures, and data evaluation procedures. The quality of the measurement data is assured by laboratory intercomparisons as well as on-site comparisons with reference instruments. This paper describes the measurement sites, instrumentation, quality assurance, and data evaluation procedures in the network as well as the EBAS repository, where the data sets can be obtained (doi:10.5072/guan).
\end{abstract}




\section{Introduction}

Atmospheric aerosol particles, or particulate matter (PM), are essential constituents in the atmosphere influencing issues such as atmospheric visibility, global climate, and human health. A climate-relevant effect is their interaction with solar shortwave radiation (Ramanathan et al., 2001). Two major aerosol effects influencing the terrestrial radiation budget have been distinguished: direct radiative forcing - scattering and absorption of upwelling and downwelling radiation in the absence of clouds (Haywood and Boucher, 2000) - and indirect radiative forcing - the modification of cloud radiative properties through the activation of additional particles as cloud condensation nuclei (Lohmann and Feichter, 2005). The magnitude of direct radiative forcing depends, in general, on various properties of the aerosol particles including particle diameter and chemical composition (Bohren and Huffman, 1998) but also shape, state of mixture, and hygroscopicity (Hänel, 1976; Zieger et al., 2013). Black carbon (BC) is among the species contributing to light absorption and, thus, atmospheric warming. According to a recent survey, the radiative forcing due to $\mathrm{BC}$ can, at present, only be bound to the uncertainty of a factor of 2 (Bond et al., 2013). The particle number size distribution and the light absorption coefficient are useful parameters to predict the direct radiative forcing on the basis of in situ measurements.

On the other hand, ambient aerosol particles have been recognised to affect human health (e.g. Dockery and Pope, 1994; Pope et al., 2004; Dockery and Stone, 2007). Recent projections of health effects yield drastic numbers of morbidity and premature deaths due to particulate pollution worldwide (Lelieveld et al., 2015). In the European Union, the mass concentration of $\mathrm{PM}_{10}$ and $\mathrm{PM}_{2.5}$ (particles smaller than 10 and $2.5 \mu \mathrm{m}$ in aerodynamic diameter, respectively) currently serve as legal metrics to assess a population's exposure to ambient particles (European Council, 2008/50/EC). A rationale for using $\mathrm{PM}_{10}$ and $\mathrm{PM}_{2.5}$ has been the large body of epidemiological evidence of adverse health effects based on these metrics.

Some studies, however, have suggested that the massbased metrics might not be the most favourable parameter to characterise PM-induced health effects (HEI Review Panel on Ultrafine Particles, 2013). Some epidemiological studies have associated health endpoints with the number of ultrafine particles or the particle surface area rather than particle mass (Ibald-Mulli et al., 2002; Franck et al., 2011; Rückerl et al., 2011). Ultrafine particles are ubiquitous in urban atmospheres (Kumar et al., 2014), and their ability to penetrate deep into the human body after inhalation has been forwarded as a rationale for their adverse health effects. A recent overview by the world health organisation WHO (Janssen et al., 2012) also counted atmospheric soot particles (BC) among the relevant environmental risk factors for human health. While there seems little doubt about the potential adverse health effects of ultrafine particles and $\mathrm{BC}$, their rel- atively low mass concentration makes them hardly accessible by total-mass-based measurements. Particle number size distribution and $\mathrm{BC}$ mass concentration have consequently been recommended as exposure parameters for future epidemiological studies (HEI Review Panel on Ultrafine Particles, 2013).

International observation networks for in situ atmospheric aerosol measurements include WMO-GAW (World Meteorological Organization Global Atmosphere Watch) and EMEP (European Monitoring and Evaluation Programme). European research infrastructure programmes have contributed to the systematic collection of in situ atmospheric aerosol data as well: EUSAAR (European Supersites for Atmospheric Aerosol Research) and ACTRIS (Aerosols, Clouds, and Trace gases Research InfraStructure Network). In the early 2000s the Nordic Aerosol Network carried out particle number size distribution measurements in a number of rural locations in Scandinavia (Tunved et al., 2003). The nature of most of these networks, however, has been to measure aerosol abundance and characteristics on a continental and global scale. Accordingly, the measurement sites are predominantly located in rural settings where direct anthropogenic influence is weak. Observation networks including urban sites are, for example, the Black Carbon and Particle Numbers and Concentrations Networks in the UK, operated by the National Physical Laboratory (Jones et al., 2012).

Government air quality networks in Europe operate many stations that collect data on $\mathrm{PM}_{10}$ and $\mathrm{PM}_{2.5}$ mass concentrations, which are relevant to European air quality legislation. In the view of limited financial resources, however, there is usually a limited incentive to measure aerosol and PM metrics that go beyond legal requirements, although such activities might provide enhanced scientific insights into climaterelevant or health-related processes.

In 2008, the German Federal Environment Agency (UBA) and the Leibniz Institute for Tropospheric Research (TROPOS) founded a new Germany-wide network for the characterisation of fine and ultrafine particles in the atmospheric aerosol. Several of UBA's manned background monitoring stations and numerous other legal and research institutions with their personnel and existing infrastructure have been involved. Notable institutions have included the Saxon State Office for Environment, Agriculture and Geology (LfULG), the Helmholtz Zentrum Munich (HMGU), the Institute of Energy and Environmental Technology (IUTA), and the German Meteorological Service (DWD). As a result, continuous measurements of sub- $\mu \mathrm{m}$ particle number size distributions and equivalent $\mathrm{BC}$ mass concentrations have been installed and maintained at a total of 17 observation sites. This paper serves to describe in detail the characteristics of the measurement sites, the instrumentation deployed for continuous particle measurements, and the location and properties of the data files. 


\section{Concept for long-term measurements}

To date, there are wide experimental options to characterise atmospheric aerosol particles in much physical and chemical detail (e.g. McMurry, 2000; Baltensperger and Prévôt, 2008; Laj et al., 2009). The requirements of long-term deployment in a network, however, reduce these options to experimental methods that are sufficiently stable and reproducible but also financially viable. When designing the German Ultrafine Aerosol Network (GUAN) in 2008, it was decided to implement a limited number of aerosol parameter measurements only but with enhanced spatial coverage and operational reliability (Birmili et al., 2009a). The measurements include, in particular

- sub- $\mu \mathrm{m}$ particle number size distributions;

- sub- $\mu \mathrm{m}$ particle number size distributions of nonvolatile particles;

- equivalent black carbon (eBC) mass concentrations.

Number size distributions of particles in dry conditions are measured by mobility particle size spectrometers. Depending on their individual set-up, these instruments are called scanning mobility particle sizer (SMPS), twin differential mobility particle sizer (TDMPS), or twin scanning mobility particle sizer (TSMPS). Number size distributions of non-volatile particles are measured after passage through a thermodenuder at a temperature of $300^{\circ} \mathrm{C}$. (Thermodenuders remove particulate compounds that are volatile at this temperature.) eBC mass concentrations are mainly measured by multiangle absorption photometers (MAAPs). During GUAN's first operation phase (2009-2014), these instrumental methods proved robust and yielded reproducible results so that they warrant successful deployment in an observation network.

\section{Atmospheric observation sites}

Figure 1 illustrates the location of GUAN's 17 ground-based atmospheric measurement sites in Germany. Figure 2 provides maps and illustrations of the immediate surroundings of each measurement. Several Tables supply detailed information: Table 1, the characteristics of the measurement sites; Table 2, instrumental features; Table 3, co-location with other particle and air pollutant measurements; Table 4, associations with other networks, infrastructure, and research projects; Table 5, the list of institutions involved. The following text gives a brief description of each GUAN site, its measurement programme, and references for published results.

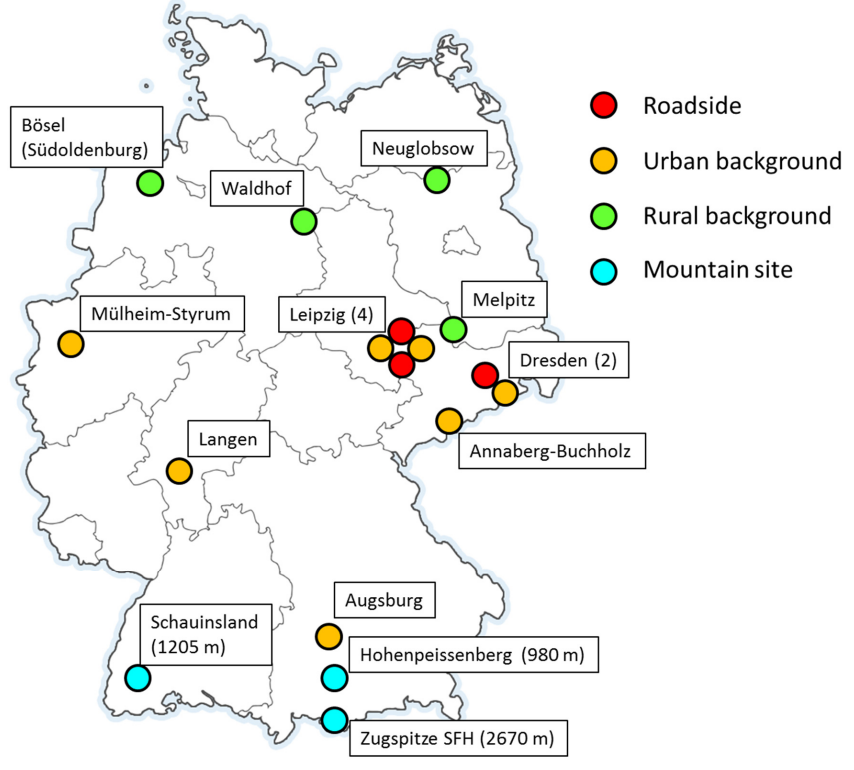

Figure 1. Location of the atmospheric observation sites in the German Ultrafine Aerosol Network (GUAN), currently consisting of 17 sites. See Table 1 for the full names and characteristics of the sites.

\subsection{Annaberg-Buchholz}

Annaberg-Buchholz is a site of the Air Quality Monitoring Network of Saxony (AQMNS) run by the Saxon State Office for the Environment, Agriculture and Geology (LfULG, Dresden). Like all AQMNS sites, technical operations are conducted by the State Department for Environmental and Agricultural Operations in Saxony (BfUL, Radebeul). The site is located in the city of Annaberg-Buchholz (population ca. 21000 ) in the Ore Mountains (Erzgebirge), distant about $10 \mathrm{~km}$ from the German-Czech border. Particle number size distributions and $\mathrm{eBC}$ mass concentrations have been measured continuously since 2012 in the framework of UltraSchwarz, a research project dedicated to ultrafine particles and health research in the German-Czech border region (Schladitz et al., 2015). The measurements are complemented by a suite of basic particulate and gaseous pollutants (cf. Table 3).

\subsection{Augsburg}

Augsburg is an urban background monitoring station operated by the Helmholtz Zentrum Munich (HMGU), Institute of Epidemiology II, and the University of Augsburg. The site was established in 2004 in the city of Augsburg (population ca. 270000) in southern Germany with a main purpose to provide input to epidemiological studies of respiratory and cardiovascular disease (KORA, cooperative health research in the Augsburg region). The station is located on the university premises, about $1 \mathrm{~km}$ south-east of the city centre. Particle number size distributions and $\mathrm{eBC}$ mass concentra- 
tions have been collected continuously since 2004 (Pitz et al., 2008; Birmili et al., 2010a; Gu et al., 2012).

\subsection{Bösel (Südoldenburg)}

Bösel (Südoldenburg) is a regular site in the government air quality monitoring system of Lower Saxony operated by the Labour Inspectorate of Lower Saxony (Staatliches Gewerbeaufsichtsamt Hildesheim, GAA). To the south, the sampling site borders agricultural areas, while to the north, it is adjacent to residential areas of the village of Bösel (population ca. 7400). The station is situated in an area where livestock production is most intense. The gaseous ammonia and organic emissions related to these activities are anticipated to have an impact on the regional budget of secondary aerosols. Bösel lies at a distance of about $100 \mathrm{~km}$ from the North Sea, so that maritime air masses can be sampled with a relatively minor impact of continental sources. Particle number size distributions and $\mathrm{eBC}$ mass concentration measurements were carried out on a continuous basis between 2008 and 2015.

\subsection{Dresden-Nord}

Dresden-Nord is another AQMNS station, located along the roadside in the city of Dresden (population ca. 500 000). Continuous particle number size distribution measurements since 2001 have confirmed a pronounced diurnal cycle of traffic-related pollutants (Löschau et al., 2010). Around 36000 vehicles pass by the site per day, including 3.5\% heavy-duty vehicles. The horizontal distances to the traffic flows range between $7 \mathrm{~m}$ (minor traffic flow; southerly direction) and $80 \mathrm{~m}$ (major traffic flow, westerly direction). The site borders the railway station Dresden-Neustadt, with mainly electrified trains passing by at a distance of $200 \mathrm{~m}$ to the north. Basic features of the particle number size distributions are presented in Gnauck et al. (2012) and Birmili et al. (2013).

\subsection{Dresden-Winckelmannstrasse}

Dresden-Winckelmannstrasse is another AQMNS station, located in the urban background of Dresden, about $1.7 \mathrm{~km}$ south of the city centre. The next major road passes by the site at a distance of $100 \mathrm{~m}$ in easterly direction. Particle number size distributions measurements were established in 2010 and $\mathrm{eBC}$ measurements in 2012. A major purpose of the site has been the provision of representative urban background concentrations for particle size distributions and particle mass within the UFIREG (Ultrafine Particles - an evidence based contribution to the development of regional and European environmental and health policy) project (Table 4). The measurements are complemented by a suite of basic particulate and gaseous pollutants (Table 3).

\subsection{Hohenpeißenberg}

The Meteorological Observatory Hohenpeißenberg (MOHp) has a long tradition of meteorological and climatological observations. It is operated by the German Meteorological Service (DWD) and contributes to WMO-GAW, ACTRIS, and EMEP. MOHp is located on a solitary hill in the rural countryside of southern Bavaria (980 ma.s.l.), approximately $40 \mathrm{~km}$ north of the Alpine mountain range. The observatory is located around $300 \mathrm{~m}$ above the surrounding rural areas, which are composed mainly of agricultural pasture $(70 \%)$ and forests $(30 \%)$. MOHp hosts a wide range of atmospheric aerosol and gas phase measurements. Some highlights include continuous observations of volatile organic compounds (VOCs), gaseous sulfuric acid $\left(\mathrm{H}_{2} \mathrm{SO}_{4}\right)$, and numerous remote-sensing parameters. MAAP measurements started in December 2003, while SMPS measurements started in 2008. The observatory has delivered atmospheric data as part of GAW since 1994, starting with elemental carbon (EC), total suspended particulate matter (TSP), and total particle number. For the basic characteristics of particle number size distributions and their relation to trace gas and meteorological parameters, see Birmili et al. (2003).

\subsection{Langen}

Langen is an urban background measurement site located on the premises of the German Federal Environment Agency (UBA) in Langen. The site is located $15 \mathrm{~km}$ south of the city of Frankfurt am Main and $5 \mathrm{~km}$ south-east of Frankfurt Airport. Aerosol particles are sampled at a height of $14 \mathrm{~m}$ on the rooftop of the UBA building. Continuous particle number size distribution measurements started in 2008, complemented since 2009 by measurements of total particle number concentrations (ultrafine condensation particle counter (UCPC), TSI model 3776) and lung-disposable surface area (nanoparticle surface area monitor, TSI model 3550) (Gerwig et al., 2014).

\subsection{Leipzig-Eisenbahnstrasse}

Leipzig-Eisenbahnstrasse is a roadside observation site in the city of Leipzig (population ca. 500000 ), operated by TROPOS since 2002. The site is located in a street canyon within a densely built-up residential area, characterised by multistorey period buildings. The street canyon is regular in that its aspect ratio is close to unity (height: $18 \mathrm{~m}$, width: $20 \mathrm{~m}$ ), and no building gaps are present. The street experiences traffic of about 12000 motor vehicles per working day. Ambient aerosol is sampled $6 \mathrm{~m}$ above street level on the northern side of the street. Due to the formation of a vortex inside the street canyon, northerly winds have been identified as the condition that favours high particle number concentrations (Voigtländer et al., 2006). For an account of the spatial and temporal variability of particle number size distributions in this area of Leipzig, see Costabile et al. (2009). 


\subsection{Leipzig-Mitte}

Leipzig-Mitte is another AQMNS station, located at the roadside in the city of Leipzig. The site borders the inner-city ring road, in close vicinity to the central train station. Immediately north of the site, three main roads merge at an intersection with daily average traffic volumes around 44000 vehicles (48000 on working day). Among all GUAN sites, Leipzig-Mitte exhibits the greatest exposure to traffic-related pollutants. $\mathrm{PM}_{10}$ mass and ultrafine particle number concentrations were discussed by Engler et al. (2012) and Ma and Birmili (2015), respectively. Leipzig-Mitte was added to GUAN for the purpose of monitoring possible changes in ultrafine particle number and $\mathrm{eBC}$ mass concentrations along with the introduction of the low-emission zone (Umweltzone) in Leipzig (Rasch et al., 2013; Löschau et al., 2015). Particle number size distribution and eBC measurements started in 2010. The station's portable cabin borders a tributary road connected to the ring road by traffic lights. Construction activities in the vicinity of the site have occasionally disturbed the measurements between 2010 and 2012. Days on which the impact of construction work was significant were documented in Löschau et al. $(2012,2013)$.

\subsection{Leipzig-Tropos}

Leipzig-Tropos (simply called "Leipzig" in some databases) is an atmospheric research station operated by TROPOS since 1997. The station is situated on the roof of the TROPOS institute building. Aerosol particles are sampled at a height of $16 \mathrm{~m}$ above the ground. High-traffic roads border the premises at distances of at least $100 \mathrm{~m}$. Comparisons of particle number size distributions at multiple sites in Leipzig have confirmed Leipzig-Tropos as an urban background station (Costabile et al., 2009; Ma and Birmili, 2015). A cross-sectional study suggested a total particle number concentration mean of $9400 \mathrm{~cm}^{-3}$, which proved to be higher than at comparable sites in Helsinki and Copenhagen (von Bismarck-Osten et al., 2013). During the heating season, the site can be influenced by a gas heating stack $50 \mathrm{~m}$ south of the aerosol inlet. Screening of the data showed that a perturbation of the measurements is likely under southerly winds and at temperatures below $0{ }^{\circ} \mathrm{C}$. The size distribution profile of the gas heating stack only affects particle number concentration below $30 \mathrm{~nm}$.

\subsection{Leipzig-West}

Leipzig-West is another AQMNS site in Leipzig, located in the western suburbs of Leipzig. The purpose of the site is to provide a second set of measurements for urban background concentrations in Leipzig. The distance to Leipzig-Mitte is about $6 \mathrm{~km}$ and that to Leipzig-Tropos about $10 \mathrm{~km}$. The residential area around the station consists of multistorey apart- ment blocks that are heated by district heating. ${ }^{1}$ The station's cabin is placed in a park area on the premises of a hospital. A minor road passes by the station around $30 \mathrm{~m}$ west of the site but has shown to have negligible influence on the measurements. Particle number size distribution and eBC measurements started in 2010 (Rasch et al., 2013).

\subsection{Melpitz}

Melpitz is an atmospheric research station operated by TROPOS since 1992. The station is located in eastern Germany near the city of Torgau and is ca. $50 \mathrm{~km}$ northeast of Leipzig. The site is surrounded by flat and seminatural grasslands without any obstacles in any directions. Besides GUAN, Melpitz contributes to WMO-GAW as a regional background site as well as ACTRIS and EMEP. Measurements at Melpitz can be taken as representative of the central European background atmosphere (Asmi et al., 2011). Melpitz hosts a wide suite of physical and chemical measurements of atmospheric aerosols (Birmili et al., 2008). The site has proved useful to detect long-range pollution transport from continental areas in an easterly direction (Spindler et al., 2010). The distance to the North Sea is about $400 \mathrm{~km}$ in a north-westerly direction and that to the Atlantic Ocean about $1000 \mathrm{~km}$ in a westerly direction. An account of the basic aerosol characteristics can be found in Engler et al. (2007), Spindler et al. (2010), and Ma et al. (2014). The effects of hygroscopic particle properties on atmospheric light scattering were discussed in Zieger et al. (2014). The formation of new atmospheric particles from gaseous precursors has been analysed here since the 1990s (Birmili and Wiedensohler, 2000; Größ et al., 2015).

\subsection{Mülheim-Styrum}

Mülheim-Styrum is part of the air quality monitoring network of North Rhine-Westphalia (LUQS). The site is operated by the State Agency for Nature, Environment, and Consumer Protection (LANUV). IUTA Duisburg operates an additional portable cabin for research measurements. The site is situated within a residential area but is also within reach of a motorway (around $250 \mathrm{~m}$ to the north), a national road (B223, around $400 \mathrm{~m}$ to the west), and industrial premises (around $600 \mathrm{~m}$ to the east and south). Overall, the site qualifies as an urban background monitoring station (Quass et al., 2004) and has been used for exposure assessment in healthrelated studies (ESCAPE, European Study of Cohorts for Air Pollution Effects) and source apportionment studies (Beuck et al., 2011). Mülheim-Styrum was added to GUAN as a representative for the Ruhr district, the largest urban agglomeration in Germany. Continuous particle number size distribution measurements started in 2008. Lung-disposable surface

\footnotetext{
${ }^{1}$ Hot water is generated in a central power plant $20 \mathrm{~km}$ away and delivered to the area through pipelines. Due to this distance, it is expected that any emissions generated at the power plant will have no influence on the local measurements at Leipzig-West.
} 


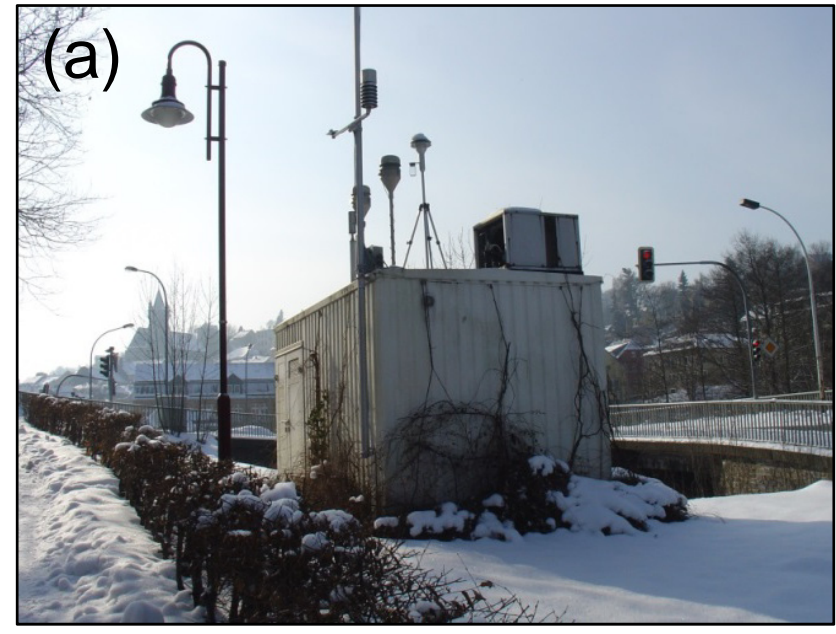

Site 1: Annaberg-Buchholz (urban background)

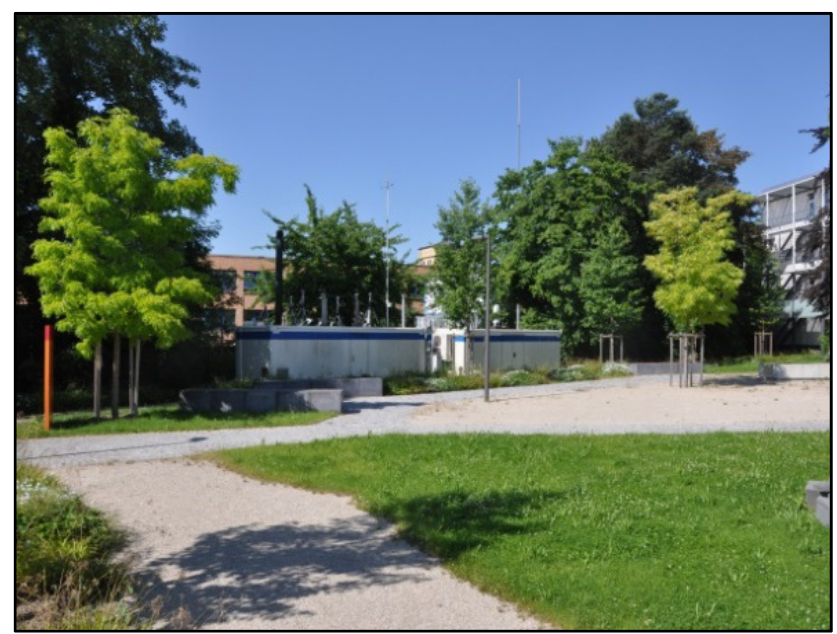

Site 2: Augsburg (urban background)

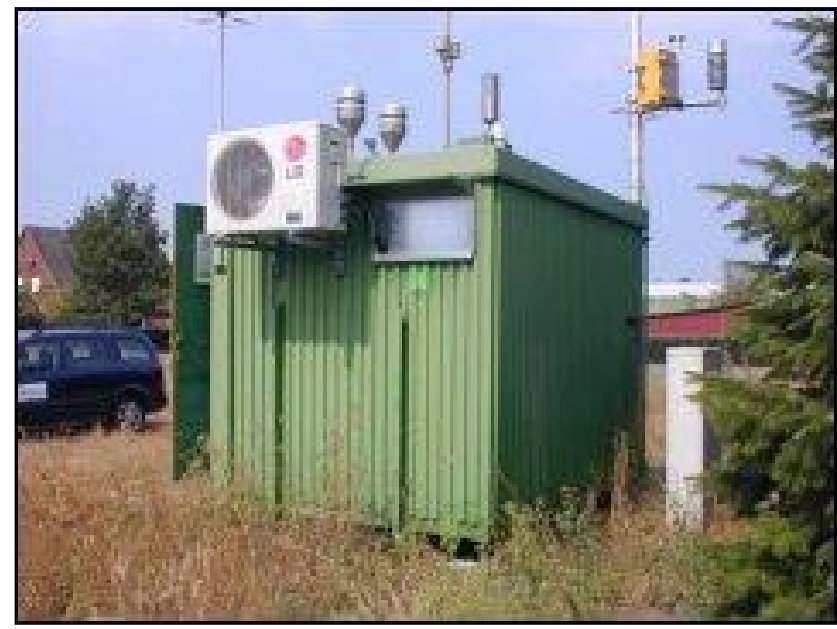

Site 3: Bösel/Südoldenburg (rural)

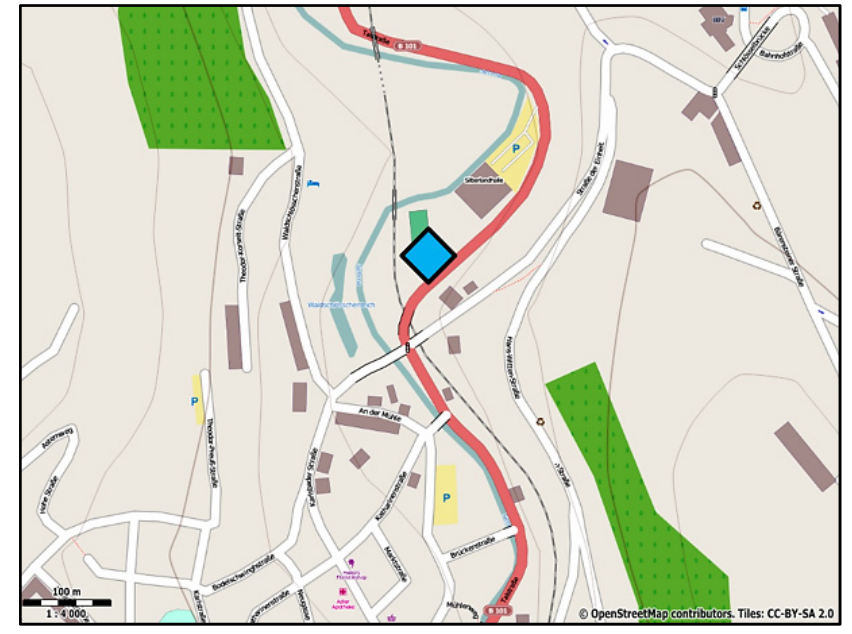

Operator: LfULG

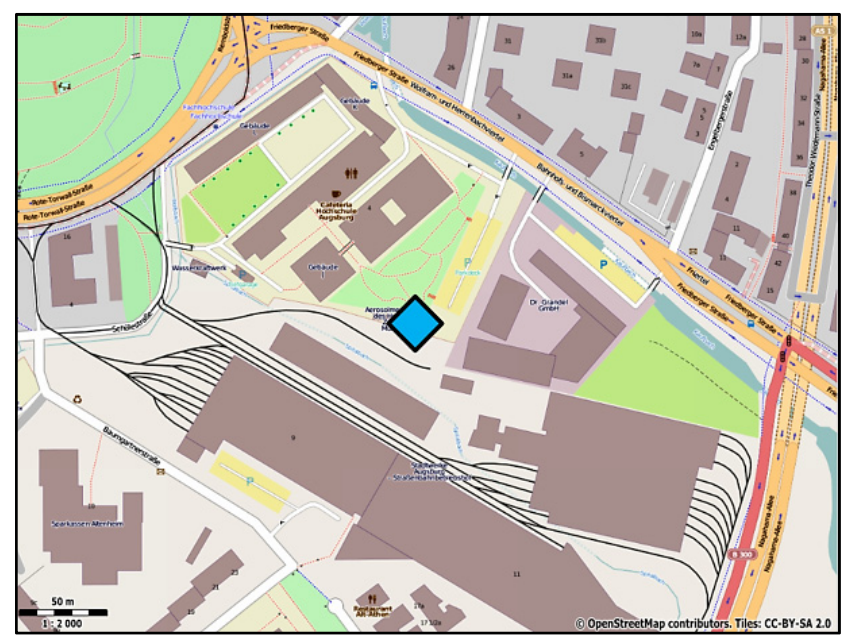

Operator: HMGU/UA

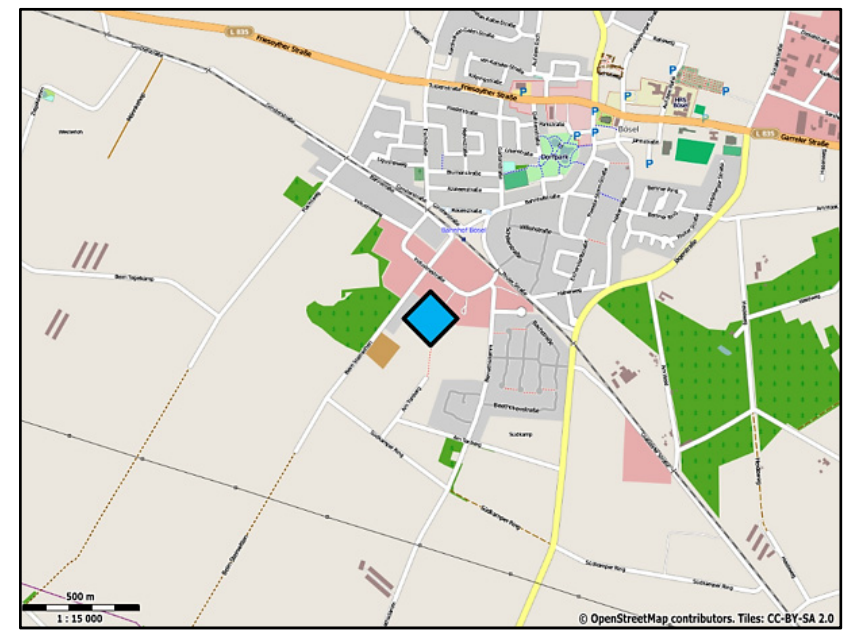

Operator: GAA

Figure 2. 


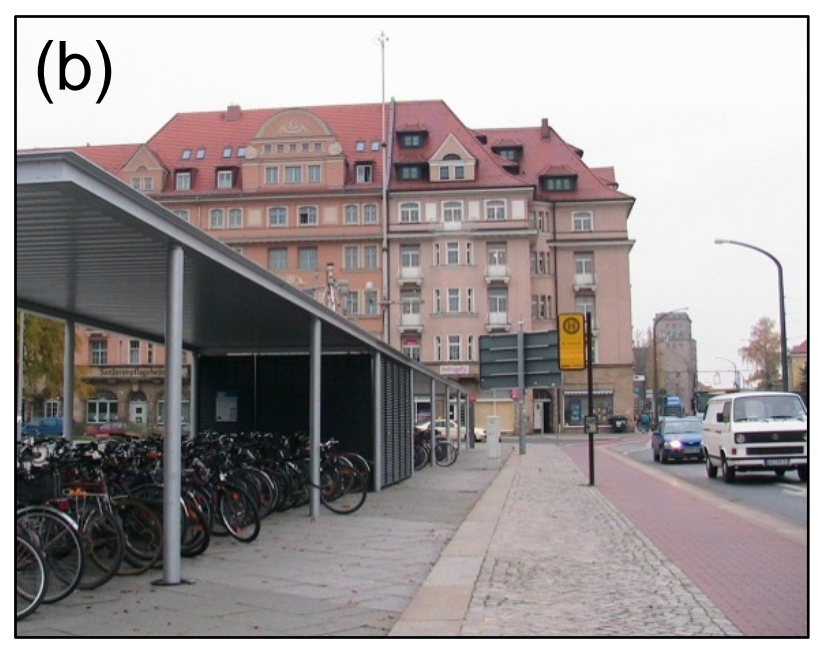

Site 4: Dresden-Nord (roadside)

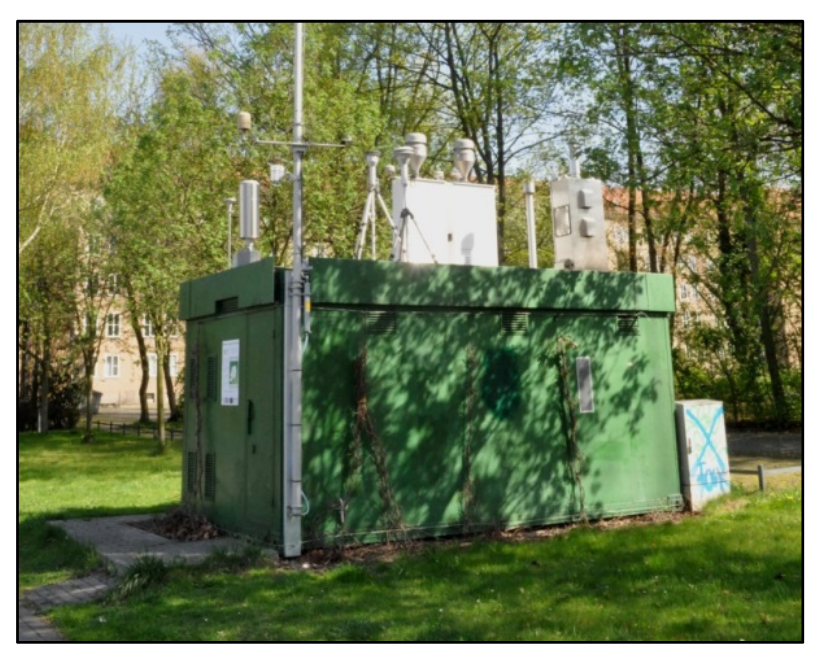

Site 5: Dresden-Winckelmannstr. (urban background)

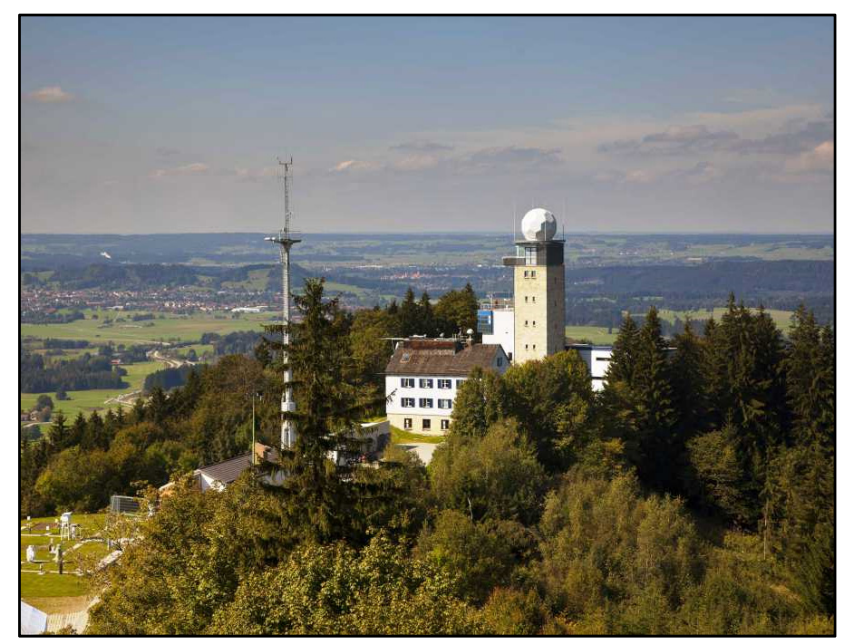

Site 6: Hohenpeißenberg (rural, mountain)

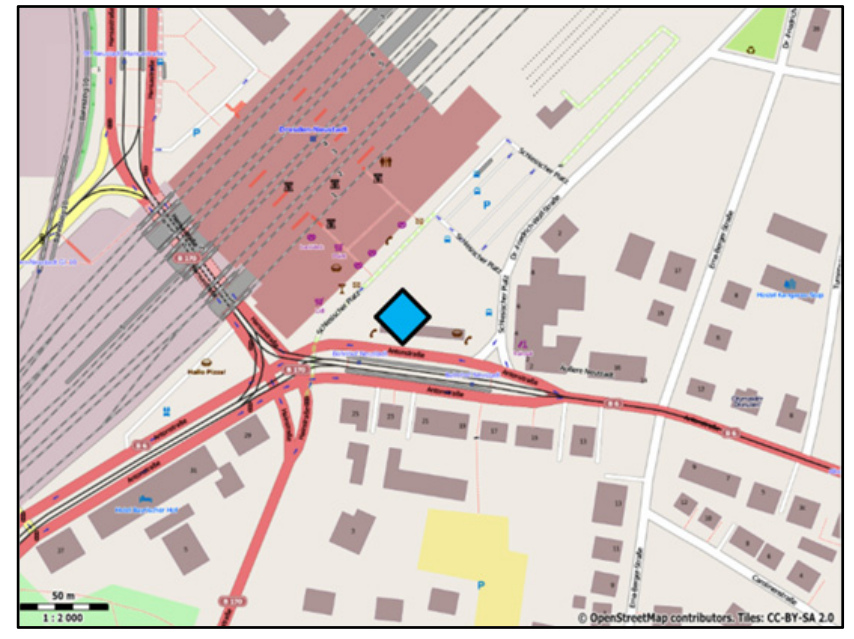

Operator: LfULG

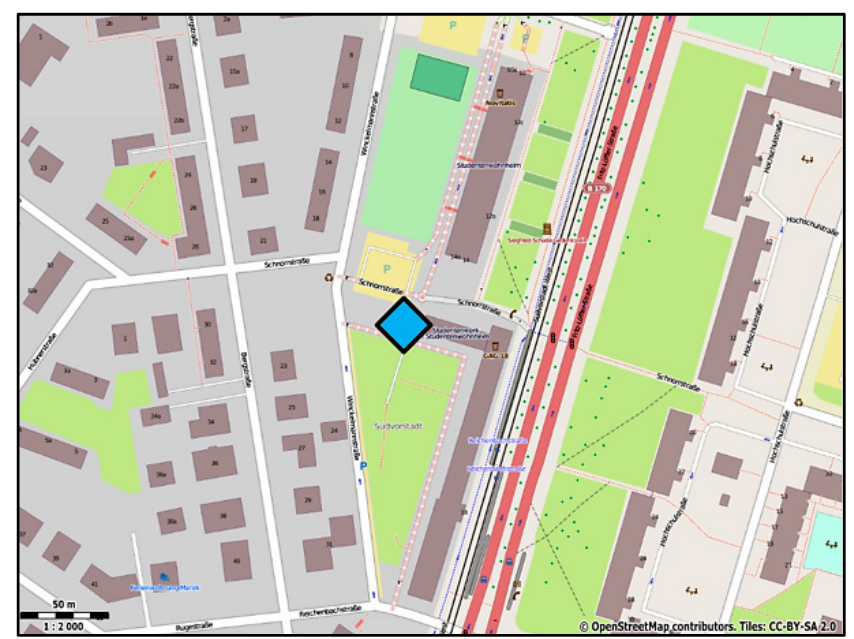

Operator: LfULG

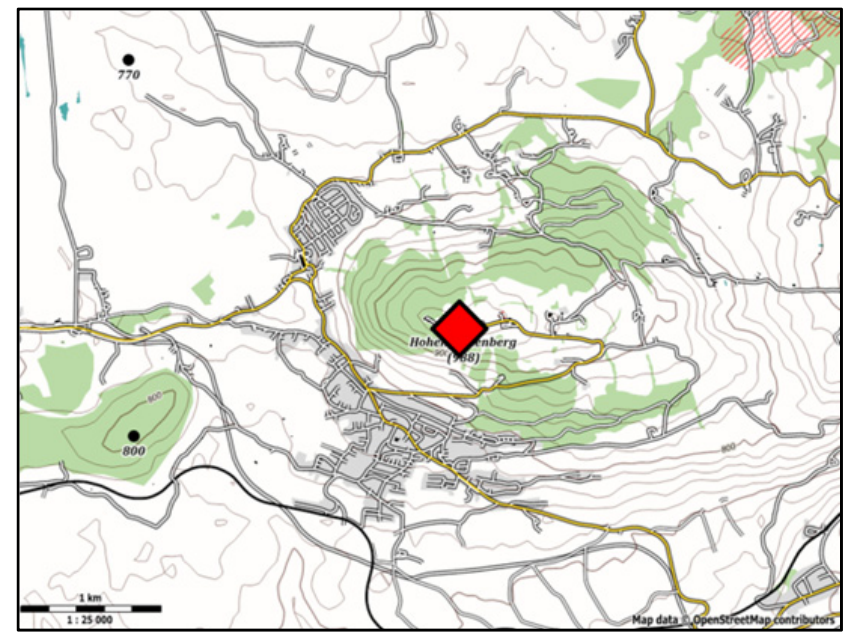

Operator: DWD

Figure 2. 


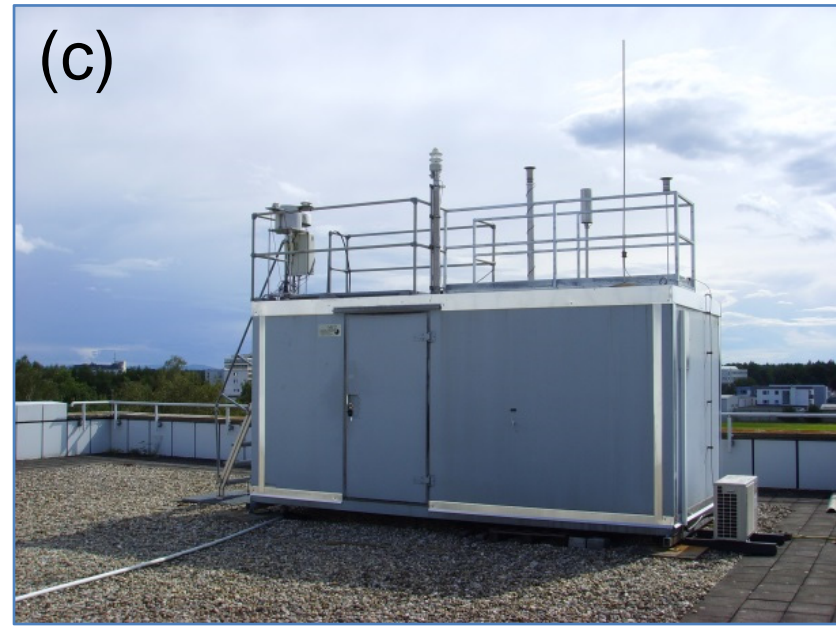

Site 7: Langen (urban background)

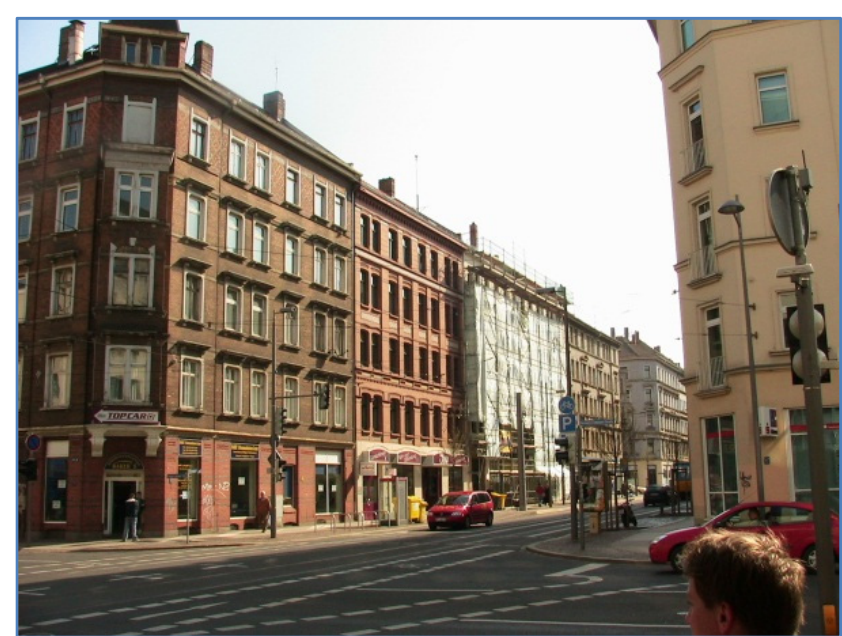

Site 8: Leipzig-Eisenbahnstr. (roadside)

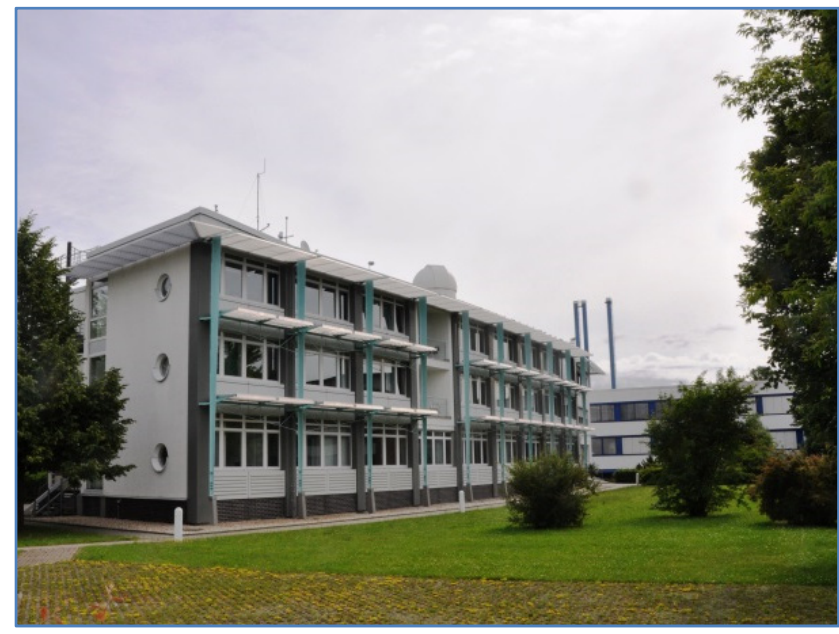

Site 9: Leipzig-TROPOS (urban background)

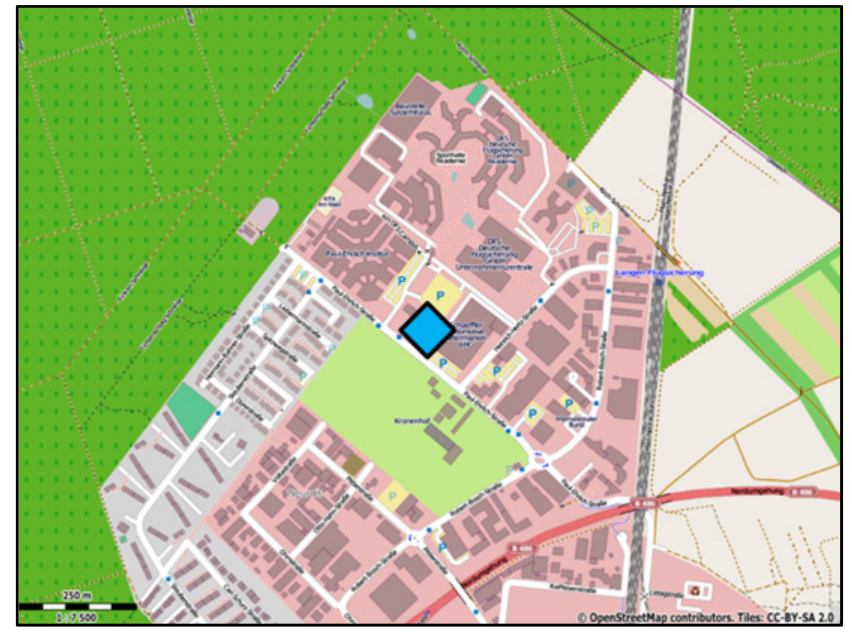

Operator: UBA

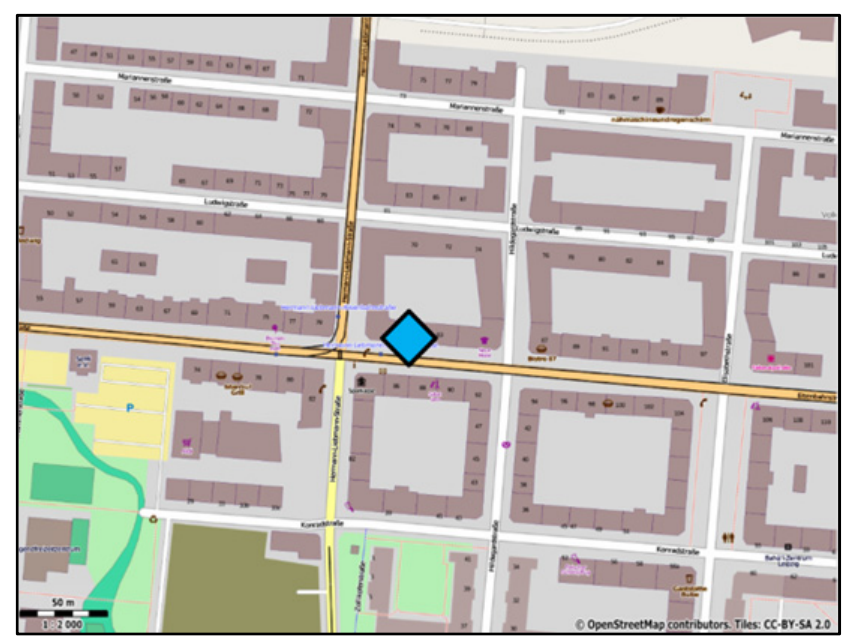

Operator: TROPOS

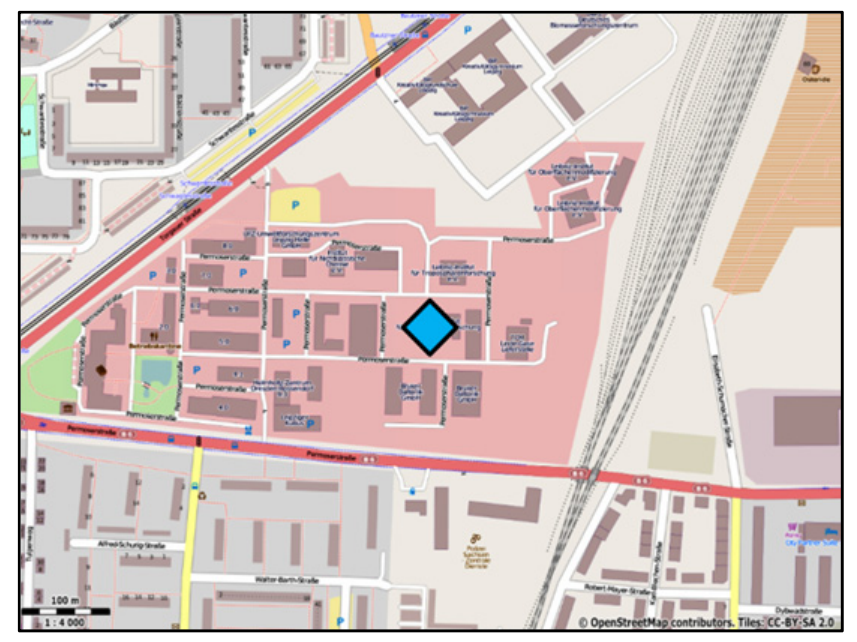

Operator: TROPOS

Figure 2. 


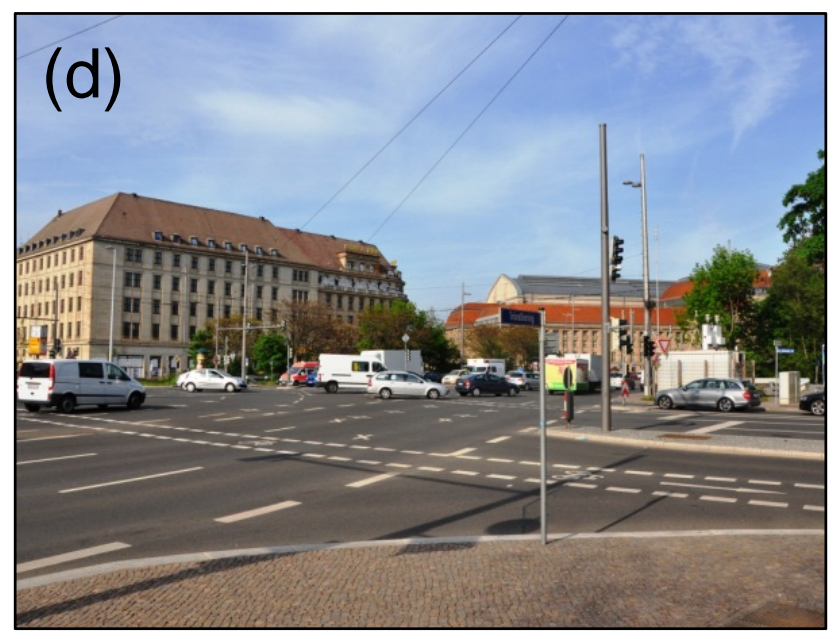

Site 10: Leipzig-Mitte (roadside)

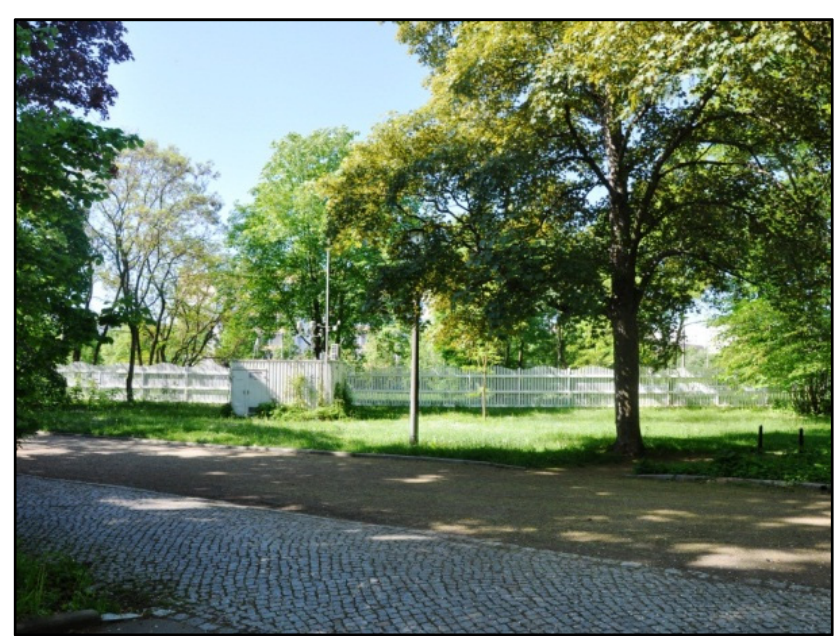

Site 11: Leipzig-West (urban background)

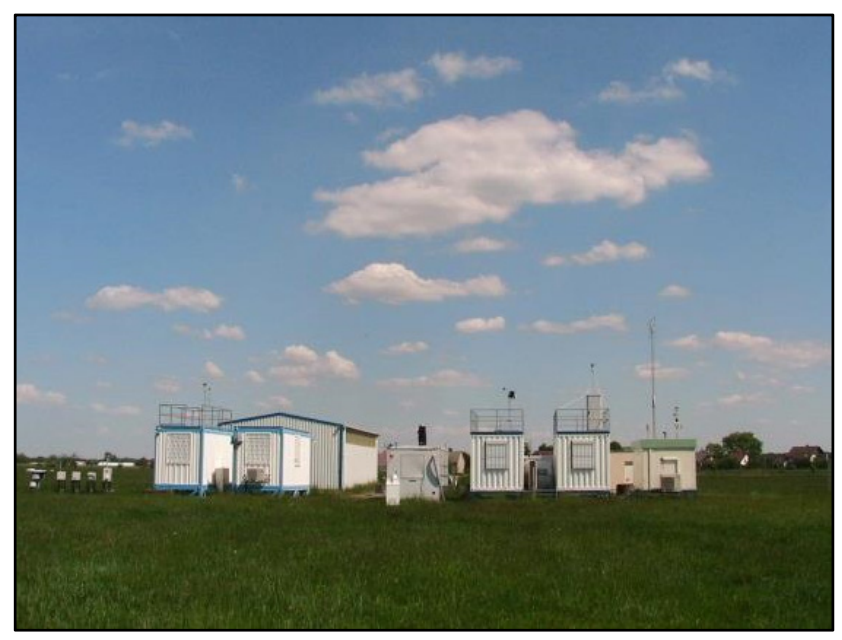

Site 12: Melpitz (rural)

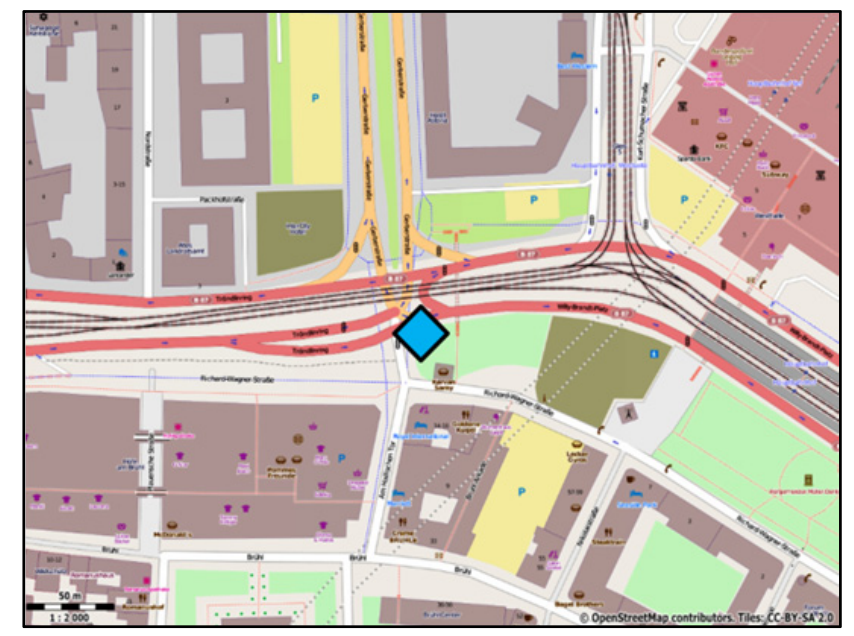

Operator: LfULG

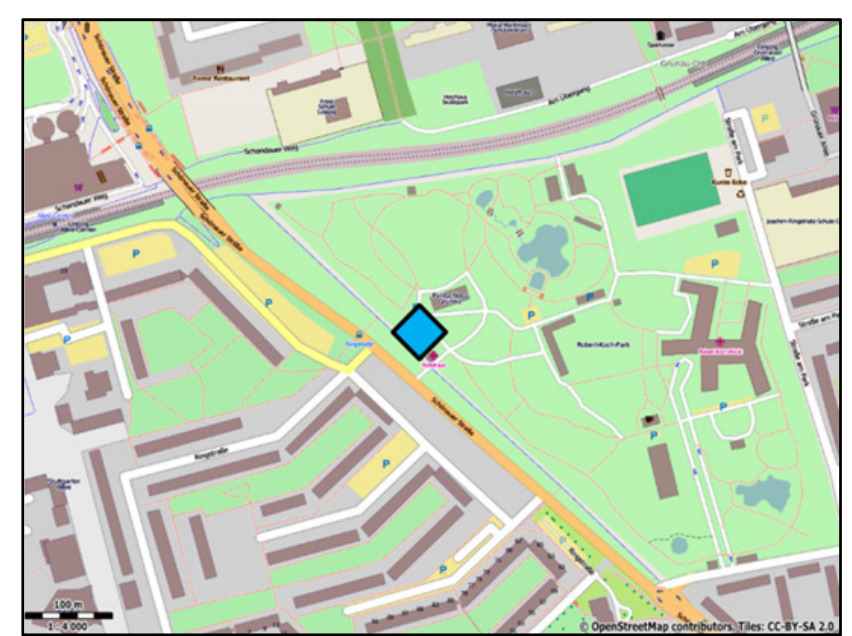

Operator: LfULG

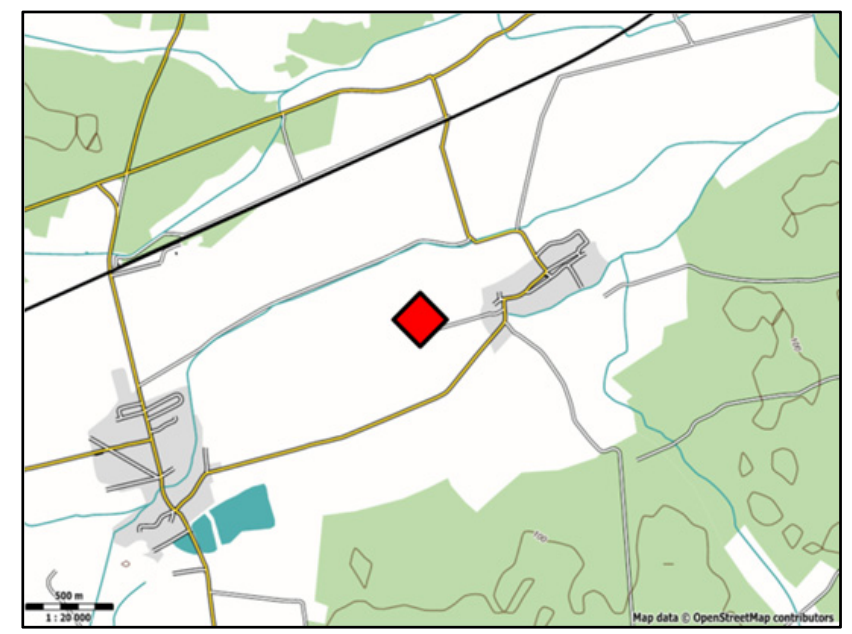

Operator: TROPOS

Figure 2. 


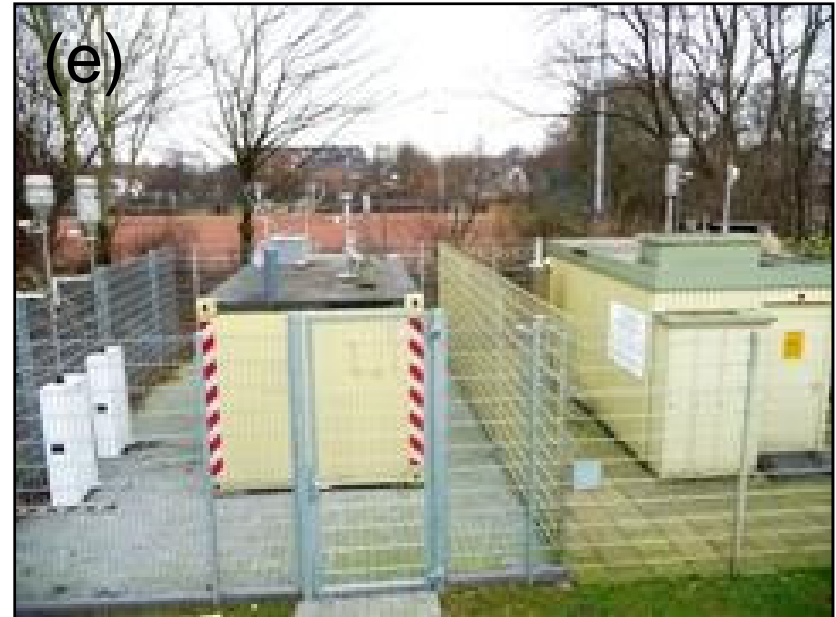

Site 13: Mülheim-Styrum (urban background)

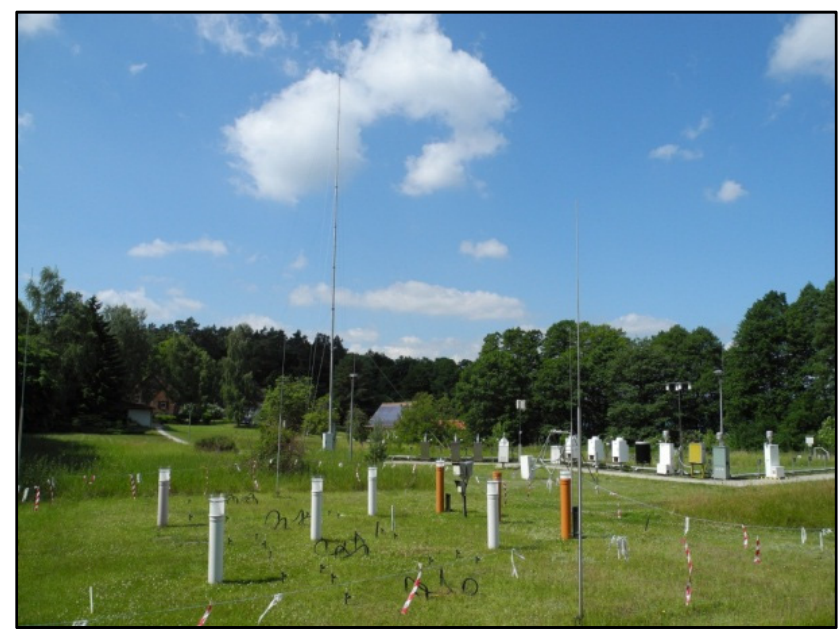

Site 14: Neuglobsow (rural)

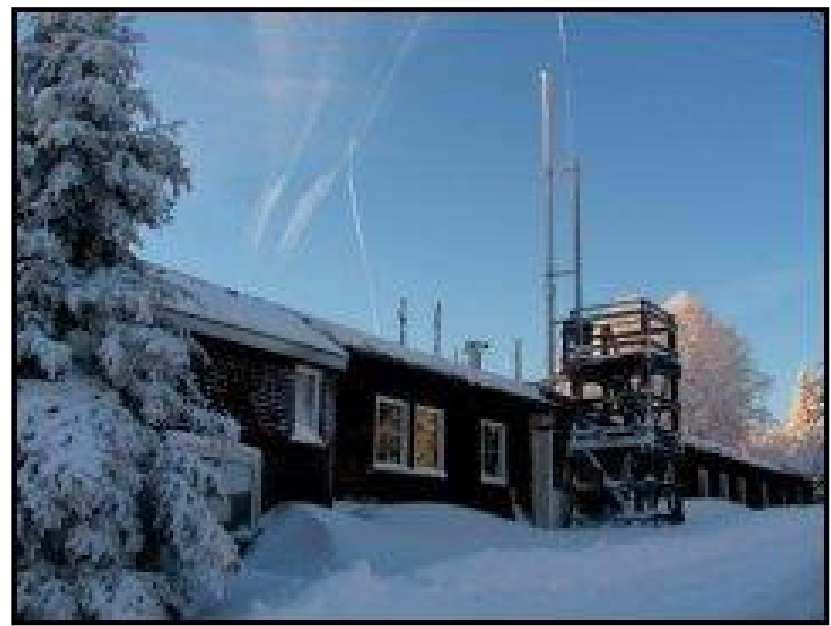

Site 15: Schauinsland (rural, mountain)

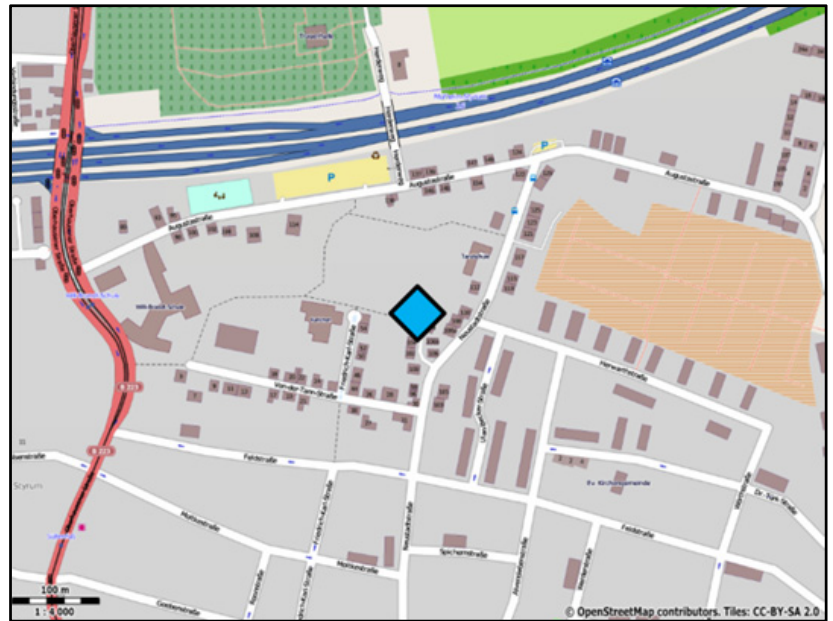

Operator: IUTA/LANUV

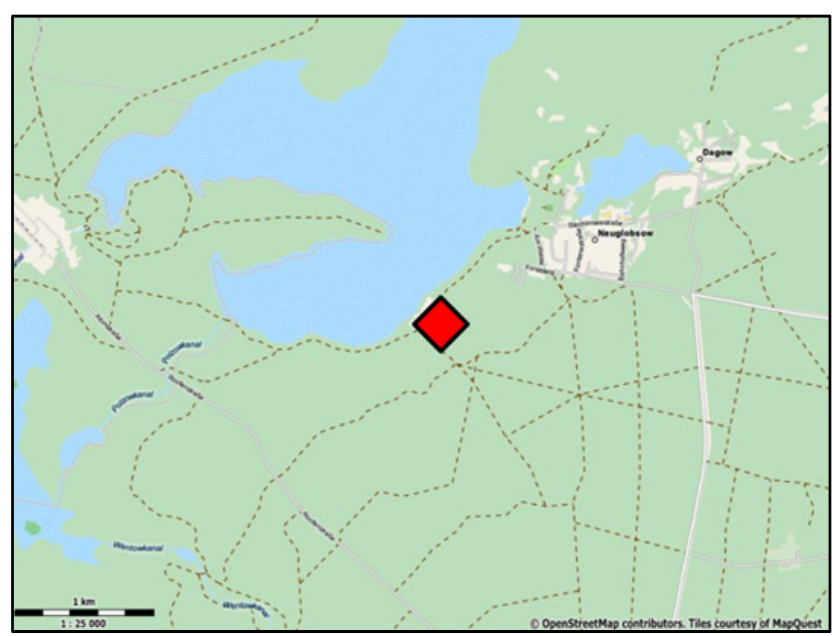

Operator: UBA

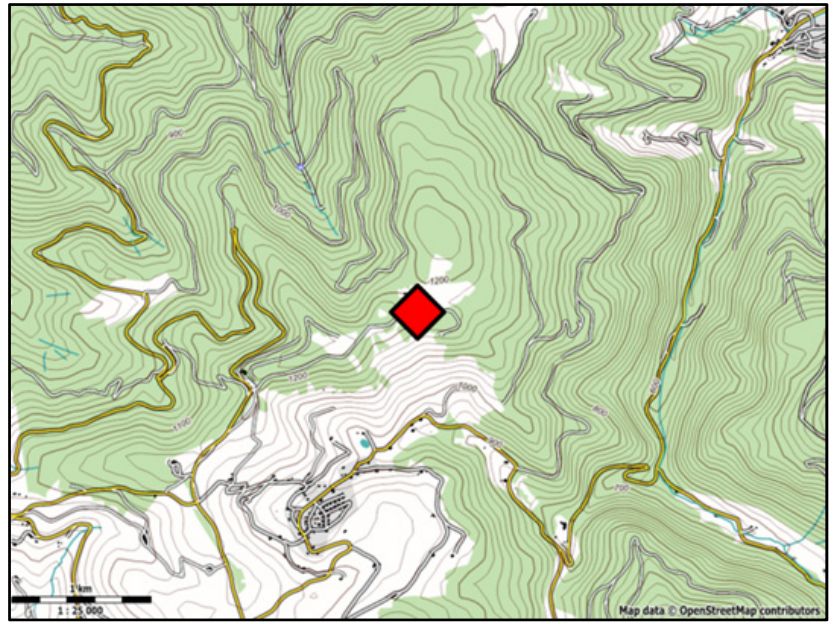

Operator: UBA

Figure 2. 


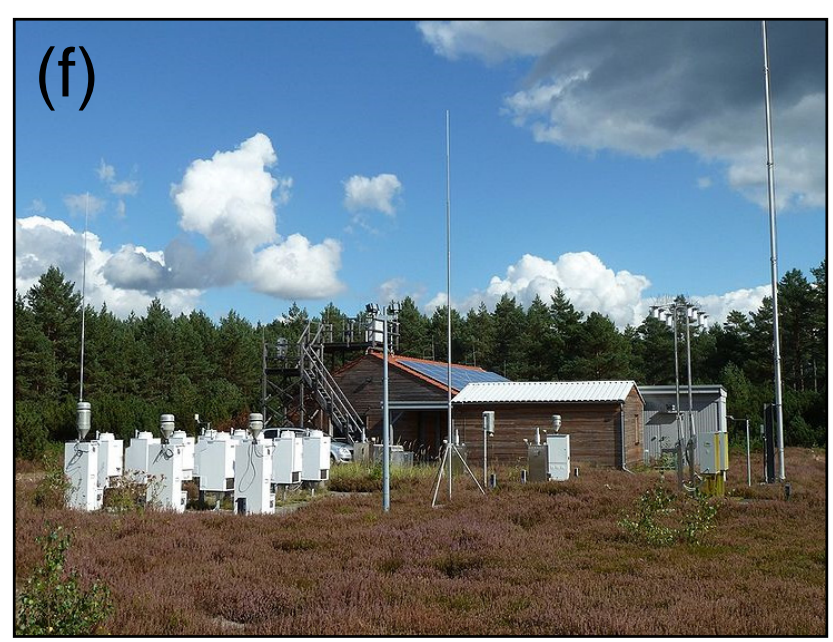

Site 16: Waldhof (rural)

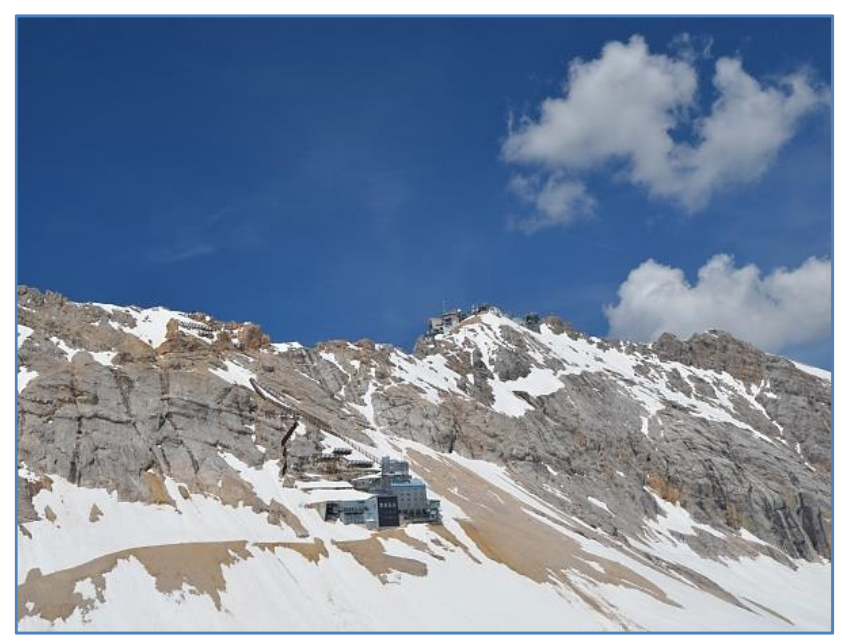

Site 17: Zugspitze/Schneefernerhaus

(Alpine mountain)

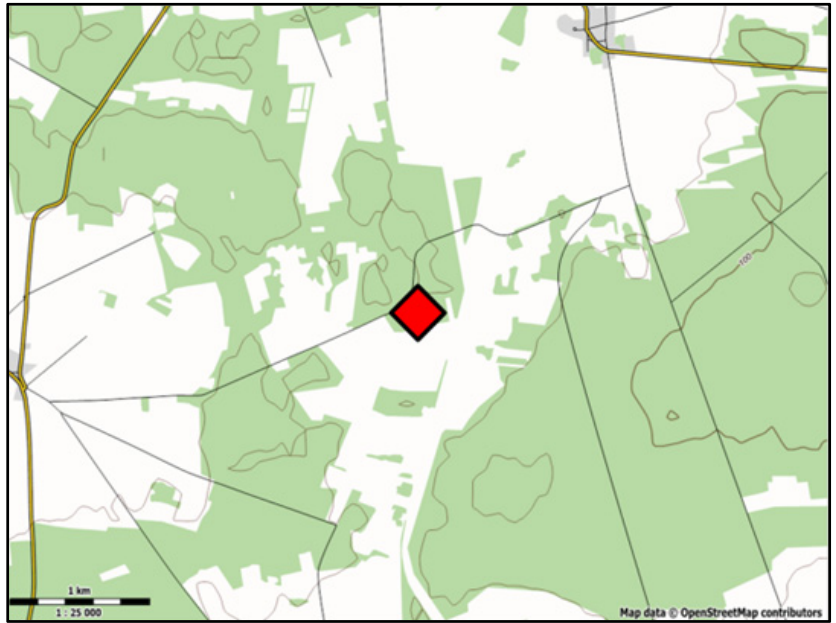

Operator: UBA

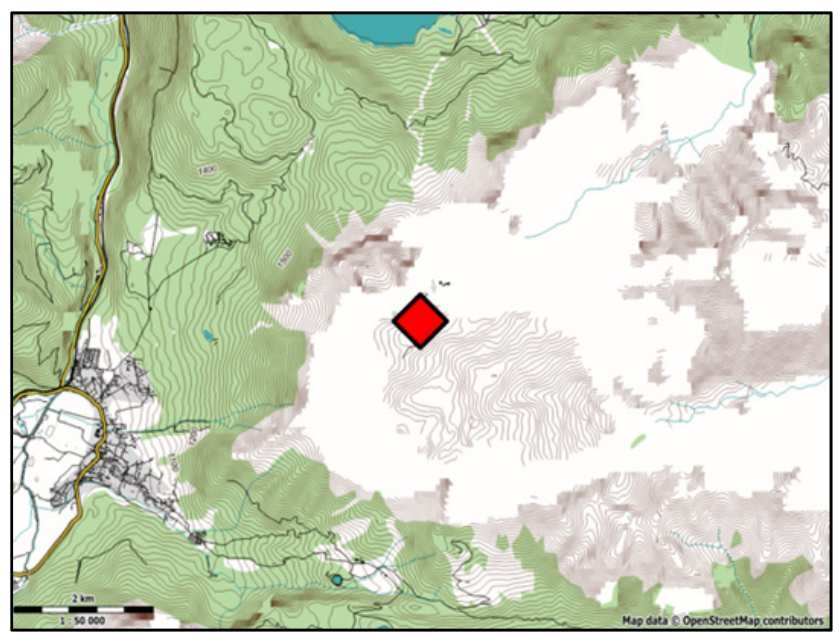

Operator: UBA/DWD

Figure 2. Illustration of the GUAN measurement sites: (a) sites 1-3, (b) sites 4-6, (c) sites 7-9, (d) sites 10-12, (e) sites 13-15, (e) sites 16-17. Pictures illustrate the surroundings of each station. The maps show the geographic area, illustrating major types of land use (Source: OpenStreetMap, processed by Maperitive V.2.3.22). The location of each measurement site is marked by a diamond.

area has been measured by a nanoparticle surface area monitor (TSI model 3550) as an additional measure of quality assurance.

\subsection{Neuglobsow}

Neuglobsow is one of the permanently manned stations within UBA's continuous observation network (UBA, 2013). The sampling site is surrounded by lakes and forested areas in all directions and is therefore only influenced very little by local sources. Neuglobsow contributes to EMEP. Measurements here can be taken as representative of the atmospheric background in north-eastern Germany. Particle number size distribution and $\mathrm{eBC}$ measurements started in 2010.

\subsection{Schauinsland}

Schauinsland is another of UBA's manned observatories. The station is located at $1205 \mathrm{~m}$ a.s.l. near the Schauinsland peak in the Black Forest in south-western Germany. Measurements started as early as 1965 as part of research programmes funded by the German Research Foundation (DFG). The station is well-suited to characterise air masses that approach central Europe from westerly directions. In winter, the site tends to lie in relatively clean air above the Rhine valley's inversion layer. Observations at Schauinsland have focused on the detection of long-term trends. For instance, the site hosts the longest continuous observation of carbon dioxide $\left(\mathrm{CO}_{2}\right)$ observations in Europe (since 1972; Schmidt et al., 2003). 
Particle number size distribution measurements started in 2005 and eBC measurements in 2008.

\subsection{Waldhof}

Waldhof is another manned station within UBA's observation network. The sampling site is surrounded by forest in all directions and is therefore only influenced very little by local sources. Measurements here are representative of the background in the north German lowlands. Waldhof is the only German atmospheric station contributing to GMOS (Global Mercury Observation System) (Weigelt et al., 2013). Particle number size distribution and eBC measurements started in 2008 .

\subsection{Zugspitze (Schneefernerhaus)}

Zugspitze (Schneefernerhaus) is part of the global WMOGAW station Zugspitze/Hohenpeissenberg and jointly operated by the German Federal Environment Agency (UBA) and the German Meteorological Service (DWD). The observatory is located at $2670 \mathrm{ma}$ a.s.1., about $300 \mathrm{~m}$ below the Zugspitze summit and on the southern slope of the mountain massif. The high altitude leads to a significant annual cycle in observed aerosol particle number and mass concentration, caused by different boundary layer heights in summer and winter (Birmili et al., 2009b) The station's elevated position allows us to sample air masses that had only little contact with the local boundary layer, especially in the cold season from October to March. Zugspitze occasionally receives lofted aerosol layers from remote source regions, such as North America (Birmili et al., 2010b) or the Eyjafjallajökull volcanic eruption (Schäfer et al., 2011). Besides the GUAN measurements, the Karlsruhe Institute of Technology conducts long-term measurements of total particle number concentration (condensation particle counter - CPC), particle number size distribution (optical particle counter - OPC; aerodynamic particle sizer - APS), and primary biological aerosol particles. Particle number size distribution measurements started in 2004 and eBC measurements in 2008.

\section{Instrumental set-up}

\subsection{Particle number size distributions}

Particle number size distributions are recorded on a continuous basis using mobility particle size spectrometers. Depending on the specific configuration, these can be TDMPSs (typical particle size range 5-800 $\mathrm{nm}$ ), TSMPSs (size range 5-800 nm), or SMPSs (typical size range $10-800 \mathrm{~nm}$ ). The core component of each mobility particle size spectrometer is a differential mobility analyser (DMA).
Note that in GUAN, similar to WMO-GAW, particle number size distributions are measured in a "dry state" i.e. at relative humidities (RHs) below $50 \%$. The reason is that particle size distributions from different sites should remain comparable. Atmospheric particles are known to grow significantly in diameter above RH $50 \%$ (Swietlicki et al., 2008). To prevent such effects in the instrumentation, aerosol dryers are installed upstream of each mobility particle size spectrometer and also within the sheath flow circuit (Wiedensohler et al., 2012). The actual values of RH and temperature in every instrument are stored at the EBAS database and can be accessed through the database interface there.

\subsubsection{SMPS (TROPOS design)}

The principle of the custom-built SMPS is described in detail in Wiedensohler et al. (2012). Briefly, the instrument uses a Vienna-type DMA (electrode length $28 \mathrm{~cm}$ ) with a condensation particle counter (CPC model 3772, TSI Inc.) to measure particles between 10 and $800 \mathrm{~nm}$. Before entering the DMA, ambient aerosol is conveyed to a bipolar charge equilibrium using a ${ }^{85} \mathrm{Kr}$ neutraliser. The sheath flow rate is $5 \mathrm{Lmin}^{-1}$ at an aerosol flow rate of $1 \mathrm{Lmin}^{-1}$. The highvoltage supply provides positive polarity, thus collecting negatively charged particles. The sheath air is generally circulated in a closed loop. Both the aerosol sample flow and the sheath air flow are actively dried in this instrument, thus ensuring a relative humidity during size classification below $40 \%$ at most times. Temperature, relative humidity, and pressure inside the instrument are continuously monitored. The typical time resolution for one combined upscan and downscan is $5 \mathrm{~min}$. TROPOS-designed SMPS instruments are currently deployed at the GUAN stations $1,3,5,6,14,15$, and 16 (see Table 2).

\subsubsection{SMPS (TSI design)}

Commercial SMPS instruments (model 3936, TSI Inc., Shoreview, USA) are deployed at the GUAN stations 7, 13, and 17. The sheath air to aerosol flow ratio is $5: 1 \mathrm{~L} \mathrm{~min}^{-1}$ at stations 7 and 17 - yielding a particle size range of 10 $600 \mathrm{~nm}$ - and $3: 0.3 \mathrm{Lmin}^{-1}$ at station 13 - yielding a particle size range of $14-750 \mathrm{~nm}$. Time resolution is $5 \mathrm{~min}$. The instruments at all stations were upgraded to meet the quality criteria recommended for ambient aerosol measurements by the EUSAAR and ACTRIS initiatives (Wiedensohler et al., 2012). The upgrades concern dryers for the aerosol sample flow and sheath air, as well as additional sensors for temperature, relative humidity, and pressure.

At stations 7 and 13, these upgrades took place prior to the start of measurements. At station 17, the modifications took place at the end of 2008. In addition, the high-voltage supply at station 17 was changed from negative to positive polarity and a range of up to $12.5 \mathrm{kV}$. This effect was con- 
Table 1. Atmospheric measurement sites in GUAN, in alphabetic order.

\begin{tabular}{|c|c|c|c|c|c|c|c|}
\hline No. & Name & EBAS Code & Site operator & Type & Altitude & Location & $\begin{array}{l}\text { Site and/or data } \\
\text { set description }\end{array}$ \\
\hline 1 & Annaberg-Buchholz & DE0061B & LfULG & urban background & $545 \mathrm{~m}$ & $50^{\circ} 34^{\prime} 18^{\prime \prime} \mathrm{N}, 12^{\circ} 59^{\prime} 56^{\prime \prime} \mathrm{E}$ & Schladitz et al. (2015) \\
\hline 2 & Augsburg & DE0062B & HMGU/UA & urban background & $485 \mathrm{~m}$ & $48^{\circ} 21^{\prime} 29^{\prime \prime} \mathrm{N}, 10^{\circ} 54^{\prime} 25^{\prime \prime} \mathrm{E}$ & $\begin{array}{l}\text { Pitz et al. (2008), } \\
\text { Gu et al. (2012) }\end{array}$ \\
\hline 3 & Bösel (Südoldenburg) & DE0056R & GAA & rural & $17 \mathrm{~m}$ & $52^{\circ} 59^{\prime} 53^{\prime \prime} \mathrm{N}, 07^{\circ} 56^{\prime} 34^{\prime \prime} \mathrm{E}$ & Asmi et al. (2011) \\
\hline 4 & Dresden-Nord & DE0063K & LfULG & roadside & $116 \mathrm{~m}$ & $51^{\circ} 03^{\prime} 54^{\prime \prime} \mathrm{N}, 13^{\circ} 44^{\prime} 29^{\prime \prime} \mathrm{E}$ & $\begin{array}{l}\text { Löschau et al. (2010), } \\
\text { Birmili et al. (2013) }\end{array}$ \\
\hline 5 & Dresden-Winckelmannstr. & DE0064B & LfULG & urban background & $120 \mathrm{~m}$ & $51^{\circ} 02^{\prime} 10^{\prime \prime} \mathrm{N}, 13^{\circ} 43^{\prime} 50^{\prime \prime} \mathrm{E}$ & Löschau et al. (2012) \\
\hline 6 & Hohenpeißenberg & DE0043G & DWD & rural (mountain) & $980 \mathrm{~m}$ & $47^{\circ} 48^{\prime} 06^{\prime \prime} \mathrm{N}, 11^{\circ} 00^{\prime} 34^{\prime \prime} \mathrm{E}$ & Birmili et al. (2003) \\
\hline 7 & Langen & DE0065B & UBA & urban background & $130 \mathrm{~m}$ & $50^{\circ} 00^{\prime} 18^{\prime \prime} \mathrm{N}, 08^{\circ} 39^{\prime} 05^{\prime \prime} \mathrm{E}$ & $\begin{array}{l}\text { Gerwig et al. (2014), } \\
\text { UBA (2013) }\end{array}$ \\
\hline 8 & Leipzig-Eisenbahnstr. & DE0066K & TROPOS & roadside & $120 \mathrm{~m}$ & $51^{\circ} 20^{\prime} 45^{\prime \prime} \mathrm{N}, 12^{\circ} 24^{\prime} 23^{\prime \prime} \mathrm{E}$ & $\begin{array}{l}\text { Voigtländer et al. (2006), } \\
\text { Costabile et al. (2009) }\end{array}$ \\
\hline 9 & Leipzig-Mitte & DE0067K & LfULG & roadside & $111 \mathrm{~m}$ & $51^{\circ} 20^{\prime} 39^{\prime \prime} \mathrm{N}, 12^{\circ} 22^{\prime} 38^{\prime \prime} \mathrm{E}$ & $\begin{array}{l}\text { Engler et al. (2012), } \\
\text { Rasch et al. (2013) }\end{array}$ \\
\hline 10 & Leipzig-Tropos & DE0055B & TROPOS & urban background & $126 \mathrm{~m}$ & $51^{\circ} 21^{\prime} 10^{\prime \prime} \mathrm{N}, 12^{\circ} 26^{\prime} 03^{\prime \prime} \mathrm{E}$ & $\begin{array}{l}\text { Costabile et al. (2009), } \\
\text { Ma and Birmili (2015) }\end{array}$ \\
\hline 11 & Leipzig-West & DE0068B & LfULG & urban background & $122 \mathrm{~m}$ & $51^{\circ} 19^{\prime} 05^{\prime \prime} \mathrm{N}, 12^{\circ} 17^{\prime} 51^{\prime \prime} \mathrm{E}$ & $\begin{array}{l}\text { Löschau et al. (2012), } \\
\text { Rasch et al. (2013) }\end{array}$ \\
\hline 12 & Melpitz & DE0044R & TROPOS & rural & $84 \mathrm{~m}$ & $51^{\circ} 31^{\prime} 32^{\prime \prime} \mathrm{N}, 12^{\circ} 55^{\prime} 40^{\prime \prime} \mathrm{E}$ & $\begin{array}{l}\text { Engler et al. (2007), } \\
\text { Ma et al. (2014) }\end{array}$ \\
\hline 13 & Mülheim-Styrum & DE0069B & LANUV/IUTA & urban background & $37 \mathrm{~m}$ & $51^{\circ} 27^{\prime} 17^{\prime \prime} \mathrm{N}, 06^{\circ} 51^{\prime} 56^{\prime \prime} \mathrm{E}$ & Beuck et al. (2011) \\
\hline 14 & Neuglobsow & DE0007R & UBA & rural & $70 \mathrm{~m}$ & $53^{\circ} 08^{\prime} 28^{\prime \prime} \mathrm{N}, 13^{\circ} 01^{\prime} 52^{\prime \prime} \mathrm{E}$ & UBA (2013) \\
\hline 15 & Schauinsland & DE0003R & UBA & rural (mountain) & $1205 \mathrm{~m}$ & $47^{\circ} 54^{\prime} 49^{\prime \prime} \mathrm{N}, 07^{\circ} 54^{\prime} 29^{\prime \prime} \mathrm{E}$ & $\begin{array}{l}\text { UBA (2013), } \\
\text { Asmi et al. (2011) }\end{array}$ \\
\hline 16 & Waldhof & DE0002R & UBA & rural & $75 \mathrm{~m}$ & $52^{\circ} 48^{\prime} 04^{\prime \prime} \mathrm{N}, 10^{\circ} 45^{\prime} 23^{\prime \prime} \mathrm{E}$ & $\begin{array}{l}\text { UBA (2013), } \\
\text { Asmi et al. (2011) }\end{array}$ \\
\hline 17 & Zugspitze (Schneefernerhaus) & DE0054R & UBA/DWD & Alpine mountain & $2650 \mathrm{~m}$ & $47^{\circ} 25^{\prime} 00^{\prime \prime} \mathrm{N}, 10^{\circ} 58^{\prime} 47^{\prime \prime} \mathrm{E}$ & $\begin{array}{l}\text { Birmili et } \\
\text { al. (2009b, 2010b) }\end{array}$ \\
\hline
\end{tabular}

Table 2. Technical features of GUAN instrumentation. Mobility particle size spectrometers follow the TROPOS design (Sect. 4.1.1) unless stated otherwise. Two types of thermodenuders are used to measure non-volatile size distributions (Sect. 4.2).

\begin{tabular}{|c|c|c|c|c|c|c|c|c|}
\hline No. & Name & Type & $\begin{array}{l}\text { Inlet height } \\
\text { above ground }\end{array}$ & $\begin{array}{l}\text { Particle mobility size } \\
\text { spectrometer type }\end{array}$ & Size range & Thermodenuder & $\mathrm{eBC}$ instrument & $\begin{array}{l}\text { eBC cut-off } \\
\text { size }\end{array}$ \\
\hline 1 & Annaberg-Buchholz & portable cabin & $4 \mathrm{~m}$ & SMPS & $10-800 \mathrm{~nm}$ & - & MAAP & $\mathrm{PM}_{1}$ \\
\hline 2 & Augsburg & portable cabin & $4 \mathrm{~m}$ & TSMPS & $5-800 \mathrm{~nm}$ & Wehner et al. (2002) & aethalometer & $\mathrm{PM}_{2.5}$ \\
\hline 3 & Bösel (Südoldenburg) & portable cabin & $4 \mathrm{~m}$ & SMPS & $10-800 \mathrm{~nm}$ & simplistic type & MAAP & $\mathrm{PM}_{10}$ \\
\hline 4 & Dresden-Nord & portable cabin & $4 \mathrm{~m}$ & TSMPS & $5-800 \mathrm{~nm}$ & - & MAAP & $\mathrm{PM}_{1}$ \\
\hline 5 & Dresden-Winckelmannstr. & portable cabin & $4 \mathrm{~m}$ & SMPS & $10-800 \mathrm{~nm}$ & - & MAAP & $\mathrm{PM}_{1}$ \\
\hline 6 & Hohenpeißenberg & building & $12 \mathrm{~m}$ & SMPS & $10-800 \mathrm{~nm}$ & simplistic type & MAAP & $\mathrm{PM}_{10}$ \\
\hline 7 & Langen & portable cabin & $14 \mathrm{~m}$ & SMPS (TSI 3936) & $10-600 \mathrm{~nm}$ & - & - & $\mathrm{PM}_{1}$ \\
\hline 8 & Leipzig-Eisenbahnstr. & building & $6 \mathrm{~m}$ & TDMPS & $5-800 \mathrm{~nm}$ & Wehner et al. (2002) & MAAP & $\mathrm{PM}_{1}$ \\
\hline 9 & Leipzig-Mitte & portable cabin & $4 \mathrm{~m}$ & TDMPS & $5-800 \mathrm{~nm}$ & - & MAAP & $\mathrm{PM}_{10}$ \\
\hline 10 & Leipzig-Tropos & portable cabin & $16 \mathrm{~m}$ & TDMPS & $5-800 \mathrm{~nm}$ & Wehner et al. (2002) & MAAP & $\mathrm{PM}_{10}$ \\
\hline 11 & Leipzig-West & portable cabin & $4 \mathrm{~m}$ & TDMPS & $10-800 \mathrm{~nm}$ & - & MAAP & $\mathrm{PM}_{10}$ \\
\hline 12 & Melpitz & portable cabin & $4 \mathrm{~m}$ & TSMPS & $5-800 \mathrm{~nm}$ & Wehner et al. (2002) & MAAP & $\mathrm{PM}_{10}$ \\
\hline 13 & Mülheim-Styrum & portable cabin & $4 \mathrm{~m}$ & SMPS (TSI 3936) & $14-750 \mathrm{~nm}$ & - & - & $\mathrm{PM}_{10}$ \\
\hline 14 & Neuglobsow & building & $6 \mathrm{~m}$ & SMPS & $10-800 \mathrm{~nm}$ & - & MAAP & $\mathrm{PM}_{10}$ \\
\hline 15 & Schauinsland & building & $6 \mathrm{~m}$ & SMPS & $10-800 \mathrm{~nm}$ & simplistic type & MAAP & $\mathrm{PM}_{10}$ \\
\hline 16 & Waldhof & building & $6 \mathrm{~m}$ & SMPS & $10-800 \mathrm{~nm}$ & - & MAAP & $\mathrm{PM}_{10}$ \\
\hline 17 & Zugspitze (Schneefernerhaus) & building & $6 \mathrm{~m}$ & SMPS (TSI 3936) & $10-600 \mathrm{~nm}$ & simplistic type & MAAP & $\mathrm{PM}_{10}$ \\
\hline
\end{tabular}

sidered in the processing of the data by the use of a different corresponding bipolar charge distribution.

\subsubsection{TDMPS/TSMPS}

Mechanically, the TDMPS and TSMPS are dual DMA versions of the SMPS described in Sect. 4.1.1 (Birmili et al., 1999). The first subsystem combines an ultrafine Vienna-type DMA (electrode length $11 \mathrm{~cm}$ ) with a UCPC (model 3025 ,
TSI Inc., Shoreview (MN), USA) to measure particles across the range $3-80 \mathrm{~nm}$. The second subsystem combines another DMA (electrode length $28 \mathrm{~cm}$ ) with a condensation particle counter (CPC model 3010 or 3772 , TSI Inc.) to measure particles between 10 and $800 \mathrm{~nm}$. Due to enhanced measurement uncertainties below $5 \mathrm{~nm}$, only the diameter range 5-800 nm is further analysed and fed into the EBAS database. Like with the SMPS, sheath air is circulated in a closed loop at relative humidities ranging mostly between 10 and $40 \%$. The typi- 
Table 3. Co-location of GUAN measurements with other continuous aerosol and air pollutant measurements. The core of GUAN measurements include sub- $\mu \mathrm{m}$ particle number size distributions (PNSD), sub- $\mu \mathrm{m}$ particle number size distributions of non-volatile particles (NVPNSD), and equivalent black carbon mass concentrations (eBC). Additional continuous measurements may include total particle number concentration (TNC) - measured by condensation particle counters; coarse particle number size distribution CPNSD - using an aerodynamic particle sizer (APS) or an optical particle counter (OPC); nanoparticle surface area (NSA) - using an NSAM monitor; aerosol scattering coefficient $\left(\sigma_{p}\right)$ - using a nephelometer; $\mathrm{PM}_{x}$ particle mass concentrations; and basic meteorological parameters (Meteo) including $T$, RH, wind speed, wind direction, global radiation, and precipitation. These additional data need to be obtained directly from the operator of the respective measurements.

\begin{tabular}{|c|c|c|c|c|c|c|c|c|c|c|c|c|c|c|c|c|}
\hline No. & Name & PNSD & NV-PNSD & $\mathrm{eBC}$ & $\mathrm{TNC}$ & CPNSD & NSA & $\sigma_{p}$ & $\mathrm{PM}_{10}$ & $\mathrm{PM}_{2.5}$ & $\mathrm{NO}_{x}$ & $\mathrm{SO}_{2}$ & $\mathrm{CO}$ & $\mathrm{O}_{3}$ & $\mathrm{CO}_{2}$ & Meteo \\
\hline 1 & Annaberg-Buchholz & • & & • & & & & & • & - & - & • & & $\bullet$ & & • \\
\hline 2 & Augsburg & - & - & - & - & - & & & - & - & & & & & & - \\
\hline 3 & Bösel (Südoldenburg) & $\bullet$ & $\bullet$ & $\bullet$ & & & & & $\bullet$ & & $\bullet$ & • & - & $\bullet$ & & $\bullet$ \\
\hline 4 & Dresden-Nord & - & & - & & & & & - & & - & & & - & & - \\
\hline 5 & Dresden-Winckelmannstr. & - & & - & & & & & - & - & - & - & & - & & - \\
\hline 6 & Hohenpeißenberg & - & - & - & - & - & & • & - & - & - & - & - & - & - & - \\
\hline 7 & Langen & $\bullet$ & & & - & & $\bullet$ & & & & & & & & & $\bullet$ \\
\hline 8 & Leipzig-Eisenbahnstr. & - & - & - & & & & & & & & & & & & - \\
\hline 9 & Leipzig-Mitte & - & & - & & - & & & - & - & - & - & & & & - \\
\hline 10 & Leipzig-Tropos & - & - & • & & & & & & & - & - & & • & & - \\
\hline 11 & Leipzig-West & - & & • & & & & & - & - & - & & & & & - \\
\hline 12 & Melpitz & - & - & - & & - & & • & - & - & - & - & & • & & - \\
\hline 13 & Mülheim-Styrum & - & & & & & - & & - & - & - & - & - & - & & - \\
\hline 14 & Neuglobsow & - & & - & & & & & - & & - & - & - & • & & - \\
\hline 15 & Schauinsland & - & - & - & & - & & & - & & - & • & - & - & • & - \\
\hline 16 & Waldhof & - & & - & & & & & - & & - & - & - & • & - & - \\
\hline 17 & Zugspitze (Schneefernerhaus) & - & - & • & - & - & & • & - & - & - & • & - & - & - & - \\
\hline
\end{tabular}

Table 4. Associations of GUAN stations with other air quality networks, infrastructure, and research projects. For further abbreviations, see Table 5 .

\begin{tabular}{|c|c|c|c|c|c|c|c|c|c|}
\hline No. & Name & WMO-GAW ${ }^{\mathrm{a}}$ & $\mathrm{EMEP}^{\mathrm{b}}$ & UBA & ACTRIS $^{\mathrm{c}}$ & $\mathrm{AQMNS}^{\mathrm{d}}$ & $\mathrm{UFIREG}^{\mathrm{e}}$ & LLEZ $^{\mathrm{f}}$ & Others \\
\hline 1 & Annaberg-Buchholz & & & & & $\bullet$ & & UltraSchwarz $^{\mathrm{g}}$ & \\
\hline 2 & Augsburg & & & & & & $\bullet$ & & $\mathrm{KORA}^{\mathrm{h}}$ \\
\hline 3 & Bösel (Südoldenburg) & regional station & & & & & & & LÜN $^{i}$ \\
\hline 4 & Dresden-Nord & & & & & $\bullet$ & & $\bullet$ & \\
\hline 5 & Dresden-Winckelmannstr. & & & & & $\bullet$ & - & $\bullet$ & \\
\hline 6 & Hohenpeißenberg & global station & $\bullet$ & & $\bullet$ & & & & $\mathrm{DWD} \mathrm{VAO}^{\mathrm{j}}$ \\
\hline 7 & Langen & & & $\bullet$ & & & & & \\
\hline 8 & Leipzig-Eisenbahnstr. & & & & & & & $\bullet$ & \\
\hline 9 & Leipzig-Mitte & & & & & $\bullet$ & & $\bullet$ & \\
\hline 10 & Leipzig-Tropos & regional station & & & & & & $\bullet$ & \\
\hline 11 & Leipzig-West & & & & & $\bullet$ & & $\bullet$ & \\
\hline 12 & Melpitz & regional station & $\bullet$ & & $\bullet$ & & & $\bullet$ & \\
\hline 13 & Mülheim-Styrum & & & & & & & & LUQS $^{\mathrm{k}}$ \\
\hline 14 & Neuglobsow & regional station & $\bullet$ & - & & & & & \\
\hline 15 & Schauinsland & regional station & $\bullet$ & - & & & & & \\
\hline 16 & Waldhof & regional station & $\bullet$ & $\bullet$ & & & & & GMOS $^{1}$ \\
\hline 17 & Zugspitze (Schneefernerhaus) & global station & & $\bullet$ & & & & & $\mathrm{VAO}^{\mathrm{j}}$ \\
\hline
\end{tabular}

a WMO-GAW: World Meteorological Organization/Global Atmosphere Watch (http://www.wmo.int/pages/prog/arep/gaw/gaw_home_en.html, http://gaw.empa.ch/gawsis). b EMEP: European Monitoring and Evaluation Programme (http://www.emep.int).

c ACTRIS: Aerosols, Clouds, and Trace gases Research InfraStructure Network (http://www.actris.eu).

d AQMNS: Air quality monitoring network of Saxony (Luftgütemessnetz Sachsen), coordinated by LfULG, operated by BfUL.

e UFIREG: Ultrafine particles - an evidence based contribution to the development of regional and European environmental and health policy (http://www.ufireg-central.eu).

${ }^{\mathrm{f}}$ LLEZ: Leipzig low-emission zone studies (Löschau et al., 2012, 2013, 2014, 2015; Rasch et al., 2013).

$\mathrm{g}$ UltraSchwarz: Ultrafine particles and health in the Ore Mountains district and the region of Usti (Ultrafeinstaub und Gesundheit im Erzgebirgskreis und Region Usti) (http://www.ultraschwarz-ziel3.de).

h KORA: Cooperative health research in the Augsburg region (http://www.helmholtz-muenchen.de/kora).

${ }^{\mathrm{i}}$ LÜN: Air quality monitoring system in Lower Saxony (Luftüberwachungssystem Niedersachsen), operated by GAA.

j VAO: Virtual Alpine Observatory, coordinated by the Bavarian Research Alliance (http://www.bayfor.org).

${ }^{k}$ LUQS: Air quality monitoring network of North Rhine-Westphalia (Kontinuierliches Luftmessnetz), operated by LANUV.

${ }^{1}$ GMOS: Global Mercury Observation System (http://www.gmos.eu). 
Table 5. Institutions involved in GUAN, in alphabetic order.

\begin{tabular}{lll}
\hline Acronym & Name & Location (all in Germany) \\
\hline BfUL & $\begin{array}{l}\text { State Dept. for Environmental and Agricultural Operations in Saxony (Betrieb- } \\
\text { sgesellschaft für Umwelt und Landwirtschaft) }\end{array}$ & Radebeul \\
DWD & German Meteorological Service (Deutscher Wetterdienst) & Hohenpeißenberg \\
GAA & Labour Inspectorate of Lower Saxony (Staatliches Gewerbeaufsichtsamt) & Hildesheim \\
HMGU & Helmholtz Zentrum Munich, Institute of Epidemiology II & Neuherberg \\
IUTA & Institute of Energy and Environmental Technology e.V. & Duisburg \\
LANUV & State Agency for Nature, Environment and Consumer Protection in North & Essen \\
& Rhine-Westphalia (Landesamt für Natur, Umwelt und Verbraucherschutz & \\
LfULG & Nordrhein-Westfalen) & Dresden \\
TROPOS & Leibniz State Agency for the Environment, Agriculture and Geology & \\
UA & University of Augsburg & Leipzig \\
UBA & German Federal Environment Agency (Umweltbundesamt) & Augsburg \\
\hline
\end{tabular}

cal time resolution of the instrument is $10 \mathrm{~min}$. TDMPS instruments are deployed at sites 2, 4, and 12, while TDMPS instruments are operated at sites 8-11. TSMPS and TSMPS have, in principle, no major differences in hardware. In software, TSMPS use a continuous ramping of the high voltage, like in the SMPS, rather than the stepwise change used in the TDMPS.

\subsection{Non-volatile size distributions (thermodenuder)}

Upstream of some mobility particle size spectrometers, a thermodenuder (TD) is deployed as a way of removing volatile aerosol components. The standard operation mode for these extended instruments is to record size distributions upstream and downstream of the TD in alternating sampling intervals (Birmili et al., 2010a). This procedure provides a steady flow of size distributions both with and without the TD and an effective time resolution of half the original instrumental time resolution.

One thermodenuder type follows the design of Wehner et al. (2002). Volatile particle material is evaporated at a temperature of $300^{\circ} \mathrm{C}$ and subsequently removed with the assistance of active carbon in a cooling section. The temperature of $300^{\circ} \mathrm{C}$ was selected with the aim of evaporating the overwhelming mass of volatile and semi-volatile material, particularly ammonium nitrate, ammonium sulfate, and most organic carbonaceous compounds. Major compounds not removed include elemental carbon, crustal material, and sodium chloride (cf. Engler et al., 2007). Meanwhile, $300^{\circ} \mathrm{C}$ is a temperature at which charring (i.e. the incomplete combustion of oxygenated hydrocarbons) of organic compounds is avoided. A mass closure for the non-volatile particle fraction at the research station Melpitz suggested that the nonvolatile fraction at $300{ }^{\circ} \mathrm{C}$ contains not only refractory black carbon but also a comparable share of low-volatility organic aerosol compounds (LVOCs; Poulain et al., 2014).
The second, simplistic thermodenuder type consists of a simple steel tube that is heated to $300^{\circ} \mathrm{C}$ by a laboratory furnace. Excess vapours are only adsorbed by the tube walls. Such a simplistic TD has been used, for example, by Ehn et al. (2007). Experiments with ambient aerosol in Leipzig suggested that both thermodenuder designs produced equivalent results for non-volatile particle size distributions across the diameter range $10-800 \mathrm{~nm}$. The tubing acting as a TD is usually cleaned once per year.

In the TD, the aerosol sample is subject to enhanced particle losses. One can think of, e.g., diffusional as well as thermophoretic losses, which are both a function of particle size. In the Wehner-type thermodenuder, part of the sample flow passes through the active carbon filter. Therefore, this instrument was calibrated for particle losses by using spherical silver particles (solid at $300^{\circ} \mathrm{C}$ ) and by measuring the particle counts upstream and downstream of the TD. The penetration of solid particles through the Wehner-type thermodenuder was about 0.34 at $3 \mathrm{~nm}, 0.66$ at $10 \mathrm{~nm}$ and 0.85 for particles bigger than $100 \mathrm{~nm}$ at a flow rate of $2.5 \mathrm{~L} \mathrm{~min}^{-1}$. All data collected from this thermodenuder type were corrected for these losses.

\subsection{Aerosol absorption and eBC}

The aerosol absorption coefficient is measured by MAAPs. The MAAP converts the light attenuation and reflection by a particle-laden quartz fibre filter into an absorption coefficient by calculating the radiative transfer through this twolayer system (Petzold and Schönlinner, 2004). The wavelength $(\lambda=637 \mathrm{~nm})$ corresponds to the region of the solar spectrum where $\mathrm{BC}$ is the prime absorber, thus minimising interferences with "brown carbon" and mineral dust. Brown carbon and mineral dust tend, in fact, to absorb light more efficiently towards the ultraviolet wavelengths (Sun et al., 2007; Müller et al., 2009). 
Because there is no unique relationship between aerosol absorption and black carbon mass concentration, black carbon is typically reported as eBC (Petzold et al., 2013). For this purpose, the aerosol absorption coefficient $\sigma_{\mathrm{abs}}$ is converted into an $\mathrm{eBC}$ mass concentration using an experimentally determined mass absorption cross section (MAC). The manufacturer of the MAAP instrument reports a MAC value of $6.6 \mathrm{~m}^{2} \mathrm{~g}^{-1}$, which is automatically applied to all data records. An assessment of aerosol absorption using Raman spectroscopy and EC measurements as reference methods yielded a mean MAC value of $5.3 \mathrm{~m}^{2} \mathrm{~g}^{-1}$, with a range of variability between 3.9 and $7.4 \mathrm{~m}^{2} \mathrm{~g}^{-1}$ across a selection of seven GUAN sites (Nordmann et al., 2009, 2013). An intercomparison of multiple instruments showed that different MAAP instruments produce comparable results with less than 5\% inter-device variability (Müller et al., 2011). Besides eBC mass concentrations, the sample flow rate, temperature, and pressure, the MAAP yields the raw signals of loaded and blank filter material at scattering angles of 0,135 , and $165^{\circ}$. The latter parameters are stored internally in a so-called "extended data format". ${ }^{2}$ To provide accurate and comparable measurements under dry sample conditions, the MAAP aerosol flow is usually conditioned by a membrane dryer.

At Augsburg, an aethalometer (Type 8100, Thermo Fisher Scientific Inc.) is deployed using a cut-off of $2.5 \mu \mathrm{m}$. This instrument yields mean $\mathrm{eBC}$ mass concentrations that are comparable to those from a MAAP instrument. Details on this instrument can be seen in Appendix A.

Unfortunately, not all eBC measurements in GUAN use the same inlet configuration. Inlets for $\mathrm{PM}_{10}, \mathrm{PM}_{2.5}$ and $\mathrm{PM}_{1}$ are used throughout the network (Table 2). In order to harmonise the $\mathrm{eBC}$ values, the data recorded downstream of the $\mathrm{PM}_{1}$ cyclone inlets may be adjusted to the corresponding level of a $\mathrm{PM}_{10}$ inlet using suitable correction factors. The multiplication factors recommended here are 1.10 for rural sites, 1.08 for urban background sites, and 1.05 for roadside sites. These values were determined by a direct intercomparison of the readings of two MAAP instruments using a $\mathrm{PM}_{10}$ and a $\mathrm{PM}_{1}$ inlet at the sites LeipzigEisenbahnstrasse (roadside), Leipzig-Tropos (urban background), and Melpitz (rural background). Because very high correlations were found during those intercomparison experiments $\left(R^{2}=0.99\right)$, a post correction appears justified (Löschau et al., 2012).

\footnotetext{
${ }^{2}$ The extended version of the data, i.e. the raw signals at various scattering angles could come to use if at some point in the future, the radiative transfer algorithm to retrieve eBC from the MAAP measurement might be improved. The raw signals would give the possibility to recalculate $\mathrm{eBC}$ according to such a different scheme.
}

\section{Quality assurance}

Quality assurance (QA) in GUAN consists of procedures to ensure that measurements remain stable both instrument to instrument (or site to site) and instrument to standard. Temporal or spatial deviations in atmospheric pollutants often occur in the range of a few per cent of the absolute concentration of a specific parameter. The issue of QA is therefore vital to successfully address scientific questions on the basis of such data. It has been an aim in GUAN to ensure an accuracy of within a few per cent for the eBC mass concentration measurements, of a few per cent for the particle sizing accuracy in number size distributions, and of $\pm 10 \%$ for particle number concentrations over the entire measurement period.

The following paragraphs describe the state-of-the-art QA procedures for mobility particle size spectrometers, which were followed at the majority of the stations. Due to the different degree of access and availability of manpower, they may not be valid in all details at every single station and for all historical parts of the data collection. Most of these measures were co-developed within the framework of previous infrastructure projects, such as WMO-GAW, EUSAAR, ACTRIS, and research projects initiated by the Saxon State Office for Environment, Agriculture and Geology (LfULG).

\subsection{Maintenance}

\subsubsection{Weekly or biweekly inspection}

At unmanned GUAN stations, the mobility particle spectrometers and MAAPs are inspected in person at least every 2 weeks, preferably every week. At the manned GUAN stations (sites 6 and 14-17), the instrumentation is usually inspected more often, up to once per working day. At unmanned sites, remote data access has helped to check instrumental performance. Unfortunately, remote data access to unmanned stations is currently available only for a few stations (e.g. 1, 2, 4, 5, 12). The weekly or biweekly inspection of mobility particle size spectrometers includes visual checks whether all instrumental components are switched on and working correctly: high-voltage power supply, sheath air flow, and aerosol flow; CPCs; supply of CPC working liquid (butanol or water); data acquisition program; flow status and operation of the MAAP.

\subsubsection{Monthly maintenance}

A full maintenance check is typically carried out with mobility particle size spectrometers every 4 weeks. Here, the following instrumental flow rates are verified using an external reference flow meter, usually a bubble flow meter: aerosol flow rate, sheath air flow rate, flow rate of the aerosol dryer's counter flow, flow rate of the sheath air dryer counter flow. Aerosol and sheath air flow meters in the mobility particle size spectrometers are recalibrated if they deviate by more 
than 5 and $2 \%$ from their set point values, respectively. Instruments are also checked for leaks using a total particle filter. The performance of the mobility particle size spectrometers is deemed satisfactory if the total particle number collected by the instrument after a waiting time of $15 \mathrm{~min}$ does not exceed 10 particles $\mathrm{cm}^{-3}$.

The high-voltage supply for each DMA is checked with a digital multimeter, involving a verification of the high voltage between 0 and $1000 \mathrm{~V}$. Recalibrations are made if the voltages exceed defined thresholds at $0 \mathrm{~V}( \pm 3 \mathrm{~V}), 6.25 \mathrm{~V}$ $( \pm 25 \%), 100 \mathrm{~V}( \pm 10 \%)$, and $1000 \mathrm{~V}( \pm 1 \%)$. Frequently checking the high voltage is essential to provide a correct sizing of the DMA, particularly at the lower end of the particle size distribution. A NIST (National Institute of Standards and Technology, US Department of Commerce) certified particle size standard is used to verify the exact sizing of the instrument. Currently, the most popular standard is $203 \mathrm{~nm}$ Polystyrene latex (PSL) spheres, which are certified within $2.5 \%$ of the nominal particle diameter. The particles are nebulised from aqueous suspension using a jet nebulizer (e.g. PariBoy, Pari GmbH, Starnberg, Germany). If the sizing of the mobility particle size spectrometer deviates more than $2 \%$ from the standard size (i.e. is outside the interval 200-206 nm), the sheath air flow is adjusted until the DMA matches the certified diameter of the PSL particles.

\subsubsection{Annual maintenance}

The annual maintenance event includes more extensive instrumental checks and care. It is preferentially performed in a central laboratory. Many GUAN instruments are returned to the World Calibration Centre for Aerosol Physics (WCCAP; Wiedensohler et al., 2012) at TROPOS in Leipzig once a year. The annual maintenance includes check and calibration of the humidity sensors; calibration of the sheath air flow rate zero offset; check and calibration of the pressure transducer; disassembly and cleaning of the DMA(s); check of the saturator sponge inside the CPC; check and calibration of the CPC(s) against a particle number concentration standard. It has also been found important to check the activity of the charge neutraliser. $\mathrm{A}{ }^{85} \mathrm{Kr}$ beta source, for example, degrades substantially in its ion production rate after about 10 years. The annual maintenance event is also used to perform hardware improvements and software updates.

\subsection{Comparison to reference instruments}

Intercomparisons with reference instruments are essential in establishing a relationship to a defined standard. In the case of mobility particle size spectrometers, we use CPCs of a specific type (model 3010 and 3772, TSI Inc., Shoreview, USA) and an electrometer (model 3068B, TSI Inc.) as an intermediate standard for particle number concentration. It is also a standard procedure to compare a mobility particle size spectrometer once per year to a reference in- strument, which will reveal possible deviations with respect to the size-dependent instrument response. In GUAN, these intercomparisons are made in the central laboratory, at calibration workshops, or in the field as part of a "round-robin test".

\subsubsection{Laboratory intercomparisons}

Intercomparisons with the TROPOS reference mobility particle size spectrometers can be made at the WCCAP "on the fly", i.e. at short notice at most times. However, it is common practice to collect a pool of instruments, which are then examined collectively against one or two reference instruments (Wiedensohler et al., 2012). Because of their state close to the bipolar charge equilibrium, we generally prefer ambient aerosols for all instrumental intercomparisons, even if the experiments are conducted in the central laboratory. Three reference instruments are provided by WCCAP for quality assurance, which are checked regularly against each other and against total particle counters. (Reference instruments need to agree within $\pm 5 \%$ for all particle sizes between 20 and $300 \mathrm{~nm}$.) Laboratory intercomparisons are preferentially accompanied by a total particle counter (CPC). The deviation between the total particle number concentration derived from any mobility particle size spectrometer and the total particle counter must not exceed $\pm 10 \%$ for ambient aerosols. On the basis of such laboratory intercomparisons, we estimate the accuracy of the particle number concentration measured by mobility particle size spectrometers to be $\pm 10 \%$ for the diameter range $20-300 \mathrm{~nm}$. Outside this range, larger uncertainties are possible. Below $20 \mathrm{~nm}$, deviations between SMPS instruments may amount up to $50 \%$ and above $300 \mathrm{~nm}$ up to $30 \%$. TDMPS and TSMPS instruments exhibit a higher accuracy at the lower particle size end: $\pm 10 \%$ down to $10 \mathrm{~nm}$ and ca. $\pm 30 \%$ at $5 \mathrm{~nm}$.

\subsubsection{Round-robin intercomparisons}

Ideally, every mobility particle size spectrometer undergoes at least one calibration experiment per year. To bridge gaps between the scheduled WCCAP calibration workshops, the QA measures may include a round-robin test on its measurement site using a reference mobility particle size spectrometer. In practice, such field intercomparisons usually involve (a) setting up a reference instrument in parallel to the mobility particle size spectrometers on site, (b) performing parallel size distribution measurements of ambient aerosol with the reference instrument during one night (introductory performance test), (c) maintaining and/or improving the instrument in case of problems, and (d) repeating the ambient aerosol comparison for several days as a final performance test. The round-robin test usually involves checks of particle sizing and parallel measurements by a total particle counter (CPC) as well. As in the case of the laboratory intercomparisons, an agreement between the total number concentra- 
tion of a mobility particle size spectrometer and the reading of a total particle counter of $\pm 10 \%$ is required. In most practical cases, we also found a good agreement between the test and reference instruments within $\pm 10 \%$ for the diameter range $20-300 \mathrm{~nm}$.

\subsubsection{Enhanced quality assurance}

For three stations in Saxony (sites 1, 4, and 5), enhanced quality assurance measures have been developed (Schladitz et al., 2014). At these sites, the mobility particle size spectrometers are equipped with an automatic function control unit that performs unattended instrumental comparisons. First, a leak check using a total particle filter is performed every 3 days. A dedicated total particle counter (TSI model 3772, "transfer CPC") is moved to each of the three stations every 8 weeks. During a 2-week presence of the transfer CPC, the control unit will perform comparison measurements between this CPC and the particle size spectrometer every $23 \mathrm{~h}$. To avoid uncertainties due to nucleation mode particles present in the lower cut-off region of the CPC, particles at the lower end of the number size distribution are removed by a diffusion screen. For traceability, the transfer CPC is checked every 8 weeks against a dedicated reference CPC at WCCAP and once a year against a calibrated electrometer. This procedure allows an even closer tracking of the actual performance of the mobility particle size spectrometer than under less infrequent intercomparisons. In our experience, the procedure can narrow down the uncertainty with respect to particle number concentration across the diameter range of $20-300 \mathrm{~nm}$ from \pm 10 to $\pm 5 \%$.

At several sites, additional instrumentation has been used as a support for quality assurance and control: at sites 2, 6, and 17, CPCs have been deployed on a continuous basis to measure total particle number concentration. As total particle concentration can also be computed from the particle number size distribution, a divergence of the two readings can help identify instrumental problems. At sites 7 and 13, nanoparticle surface area monitors (NSAM, TSI Inc.) have been deployed as a QA tool because the lung-deposited particle surface area (LDSA) can be computed from the particle number size distribution as well. At site 13, significant deviations between the measured and calculated LDSA over several consecutive days indicated the failure of one of the instruments which, in practice, almost always turned out to be the SMPS or its CPC.

\section{Data processing and validation}

\subsection{Particle number size distribution processing}

Particle number size distributions from all stations except station 13 were processed using the TropINV software package, written in LabVIEW (Version 8.5, National Instrument, Austin, USA). This program evokes a linear multiple charge inversion algorithm (Muchain, Multiple Charge Inversion; Pfeifer et al., 2014) and performs various additional corrections before yielding the final particle number size distributions. TropINV performs the following steps:

1. reformatting the raw concentration and instrument diagnostics data (optional);

2. condensing the number of size bins of the raw data to a fraction of its original number (optional);

3. automatic flagging of periods exhibiting diagnostics data outside the nominal range;

4. assimilation of the two DMA branches (only for TDMPS and TSMPS instruments);

5. multiple charge inversion (Pfeifer et al., 2014);

6. adjustment of particle number concentrations for nonideal aerosol flow rates (optional);

7. size-dependent corrections of particle number concentration (Wiedensohler et al., 2012):

- CPC counting efficiency

- DMA transfer function

- bipolar charger

- aerosol dryer.

- connecting tubes inside and outside of the instrument

8. normalisation of ambient concentrations to $0^{\circ} \mathrm{C}$, $1013 \mathrm{hPa}$ (optional);

9. re-binning the size channels to a predefined standard set of standard channels.

Step 7 yields technically correct data that are ready for scientific use (dubbed "Level-1" in Sect. 7.2). Step 8 yields data that, after averaging to $1 \mathrm{~h}$ resolution, form "Level-2" data (Sect. 7.2). GUAN has followed a practice that during step 9, all particle number size distributions are re-binned to a uniform set of 40 channels between 10 and $800 \mathrm{~nm}$ in the case of the SMPS instrument and 46 channels between 5.1 and $800 \mathrm{~nm}$ by linear interpolation. It is expected that in this way, data processing will be facilitated for the scientific end users. The data at station 13 were processed using the Aerosol Instrument Manager software (TSI Inc., Revision G, October 2006), which performs all the necessary steps (57) in a manner equivalent to the TropINV software (Pfeifer et al., 2014). 


\subsection{Technical and manual data validation}

The first step of quality control of mobility particle size spectrometer data involves the automatic flagging of data records that are associated with invalid instrument diagnostic data. For example, the relative humidity in the instrument needs to remain below $40 \%$. Instrumental temperature needs to be within a range of +10 to $30^{\circ} \mathrm{C}$. Aerosol sampling flows are not permitted to deviate from their set point by more than $\pm 10 \%$, and the sheath air flows must not diverge more than $\pm 5 \%$ from their set point. These thresholds are motivated in Wiedensohler et al. (2012).

Further quality control involves additional visual checks by the scientists processing the data. One procedure is to carefully inspect contour diagrams of the particle number size distribution. An example for such contour diagrams at the highest available time resolution is given in Fig. 3. The human eye is rather sensitive to unusual features in such twodimensional structures, and in our experience, this visual inspection has proved very effective in detecting irregularities in the data, such as

- flash-over of high voltage between the two DMA electrodes (this unwanted effect tends to produce artificial particles at the upper end of the size distribution);

- decrease in the counting efficiency of a CPC, as a result of laser diode power degradation;

- contaminations, such as room air leaking into the instrument

- disturbing particle sources inside and outside of the measurement station.

A second tool is the screening of the time series, spanning half a year or more for the all-time maxima and minima. We look, for example, at the total particle number and volume concentrations calculated from number size distributions and review their time series and histograms for unusual outliers. Individual values far outside the main frequency distribution are then inspected more closely and, if judged as the result of technical faults, deleted from the subsequent processing.

\section{Data repository and format}

\subsection{EBAS (World Data Center for Aerosols)}

Particle number size distributions and aerosol absorption coefficients from all GUAN stations are stored at the World Data Center for Aerosols EBAS database, where they are publicly available and free of charge (Birmili et al., 2015). The GUAN data can be accessed by following the persistent identifier doi:10.5072/guan or by visiting the EBAS user interface directly (http://ebas.nilu.no). EBAS is a database infrastructure operated by NILU (Norwegian Institute for Air Research), with basic funding secured through the EMEP protocol of the Convention on Long-range Transboundary Air Pollution. EBAS handles, stores, and disseminates atmospheric composition data generated by international and national frameworks in long-term monitoring programmes and research projects and has, for instance, been used by more than 50 European Union research projects. Dedicated staff (ca. 10 persons) secure the reliability for long-term data access.

Data integrity, interpreted as quality assurance and protection of the data holdings, is secured by the following measures: each data submission to EBAS undergoes manual quality assurance for the correctness of the accompanying metadata, as well as an extra check of the data records for outliers and implausible values. Errors are iterated with the data originators until the submission passes quality assurance. Once inserted into the database, the data are backed up together with the whole database at least twice per week (two full and two incremental back-ups per week) at an offsite location.

With regard to copyright, any scientific user is free to download, copy, distribute, transmit, and adapt the data sets as long as he/she gives credit to the original authors (equivalent to the Creative Commons Attribution License). Data users accept that they should make an offer of co-authorship through personally contacting the data providers or owners whenever substantial use is made of their data. It is desired that the data users contact the data originators in order to create positive feedback and foster scientific communication. In all cases, acknowledgement must be made of the data originators and of the project name when these data are used within a publication. Tørseth et al. (2012) illustrate the possibilities of a cross-sectional study that makes extensive use of data stored at EBAS.

\subsection{Data format}

At EBAS, aerosol data are stored in three levels, reflecting an enhanced data submission protocol for particle number size distribution and $\mathrm{BC}$ mass concentration data. The objective of a three-level protocol is to enhance the traceability of measurements and data processing, ranging from instrumental raw data up to final hourly averages.

Level-0 data contain raw data, i.e. electrical particle mobility distribution data and instrumental diagnostic parameters, as they are measured directly by the instrument. The electrical particle mobility distribution is provided as an array of measured particle number concentrations vs. particle diameters (electrical particle mobility for singly charged particles).

Level-1 data are scientifically correct particle number size distributions after multiple-charge inversion and the correction for particle losses. In the case of particle number size distributions, the data refer to the original conditions during the measurement, i.e. ambient pressure at the station, and typically $20^{\circ} \mathrm{C}$ laboratory temperature. In the case of the aerosol absorption coefficient, the data refer to standard temperature 


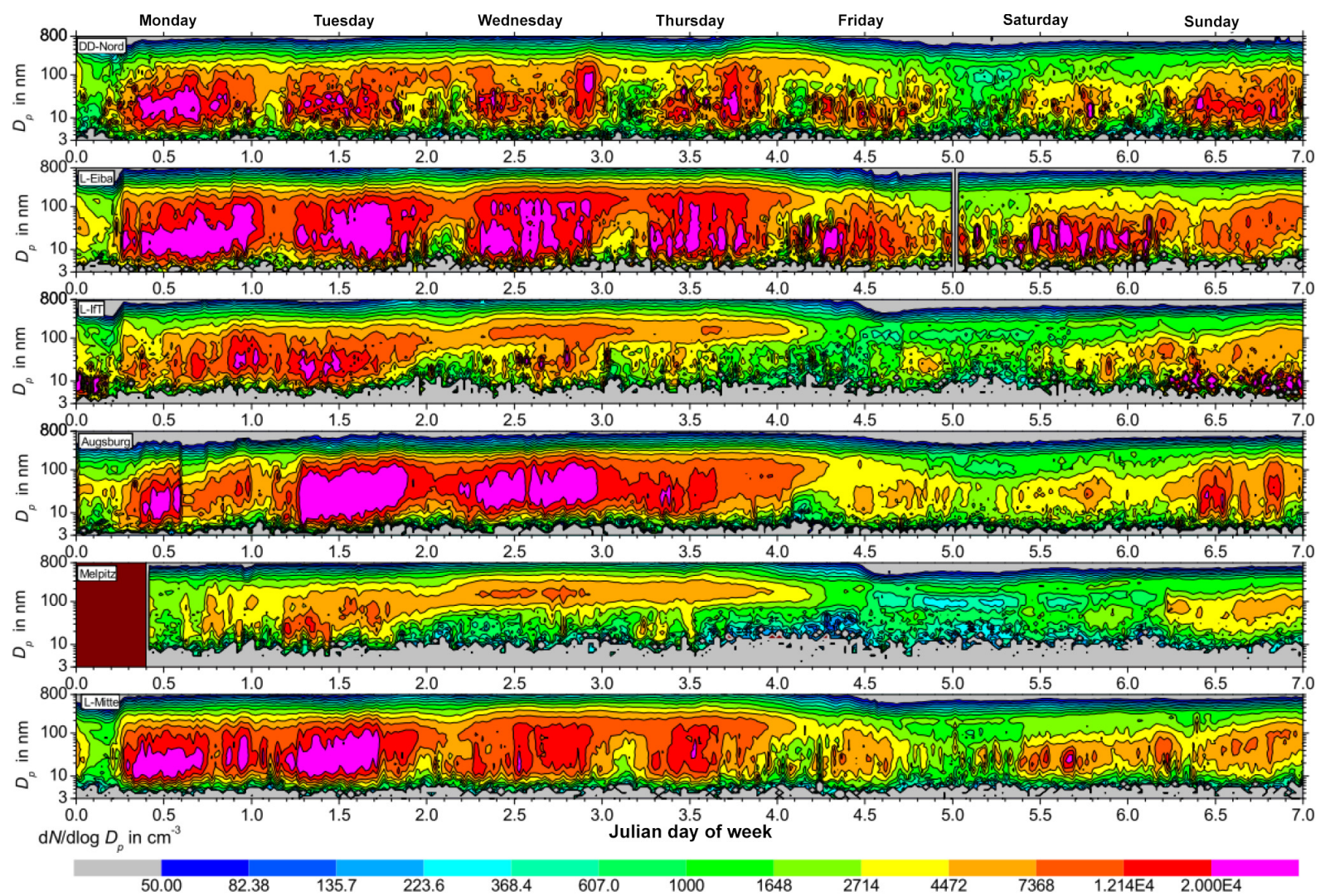

Figure 3. Exemplary contour diagrams of particle number size distributions at six mainly urban GUAN sites (20-26 December 2009). Such diagrams assist the visual quality control of the data.

$(273.15 \mathrm{~K})$ and pressure $(1013.25 \mathrm{hPa})$ already. In any case, the time resolution refers to the original instrumental time resolution.

Level-2 data are given as hourly averages and adjusted to a uniform standard temperature $(273.15 \mathrm{~K})$ and pressure $(1013.25 \mathrm{hPa})$. Moreover, most of the particle number size distribution data sets have been re-binned to the same standard set of 40 or 46 diameter channels (cf. Sect. 6.1). Level-2 data are presumed to be the main point of interest to most data users. Level-2 data are available through the EBAS user interface (see Supplement), while Level-0 and Level-1 data are available on request from the administrators of the database.

Data are stored at EBAS in the NASA-Ames format, which is based on the ASCII text NASA-Ames 1001 format but contains additional metadata specifications ensuring instrumental documentation. For more information on the format, we refer the reader to Wiedensohler et al. (2012) and the EBAS website. An extract of NASA-Ames 1001 text is provided in the Supplement.

\subsection{State of data submission}

Although data are collected continuously, the body of GUAN data currently requires some degree of manual quality control and semi-manual data post processing. Data parcels encompassing half a calendar year are currently submitted to EBAS at regular intervals. Feeding the data from all 17 GUAN stations and also non-volatile particle number size distributions into EBAS has not been completed and will require, especially in the case of some retrospective data sets, additional time. It has been our first priority to transfer all recent GUAN data spanning the years 2009-2014 into EBAS. At the time of writing, data from 2015 have been published as well. The Tables provided on GUAN's download page doi:10.5072/guan present the current state of the data submission and availability. (A snapshot of that page is also shown in the Supplement to this article.) The most complete year of data availability is 2012, with particle number size distributions available at 14 sites. The longest continuous time series are available for particle number size distributions in Dresden-Nord and Melpitz.

It needs to be mentioned that certain data sets prior to 2009 were still processed under previous data processing standards. This is a result of the EBAS repository emerging from projects that go back to the early 2000s. These older particle number size distribution data sets lack, particularly, the corrections for the losses in the internal tubing of the mobility particle size spectrometers. These losses come into ef- 

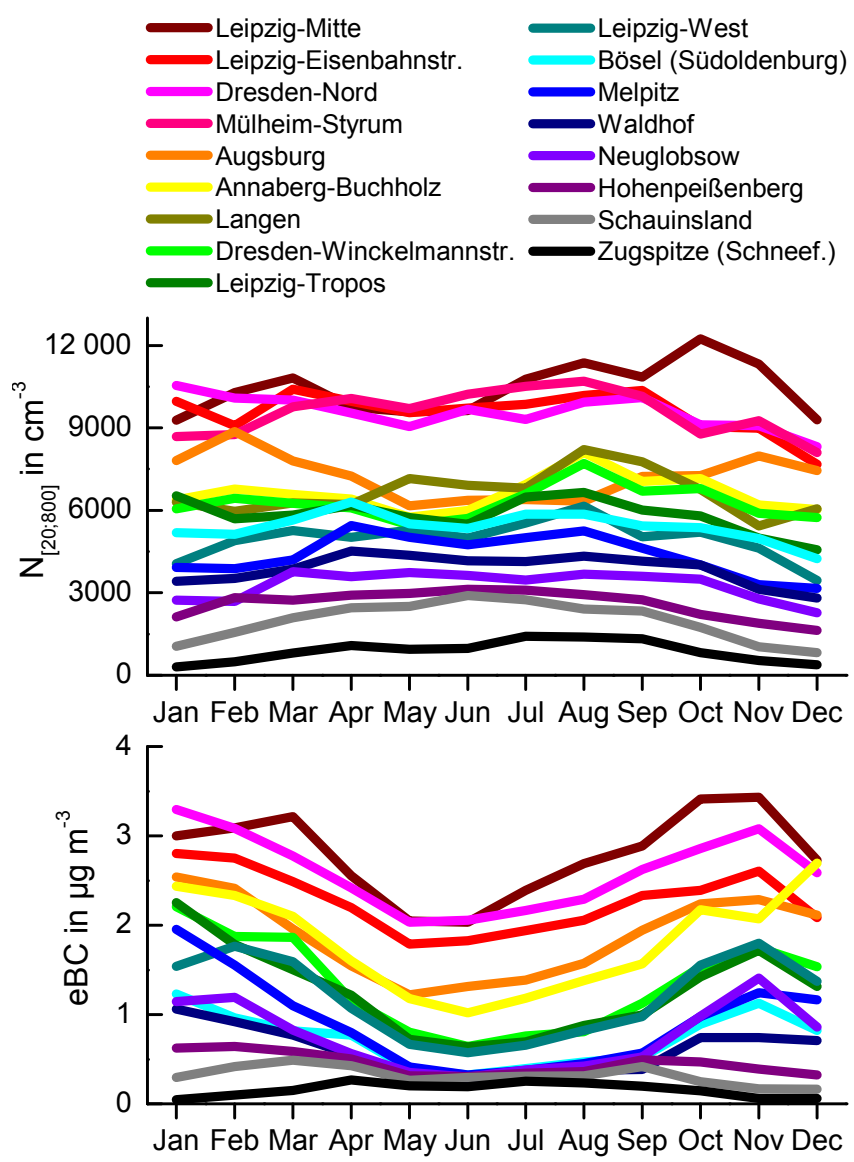

Figure 4. Preview of the mean annual cycles of total particle number concentration $\left(N_{[20 ; 800]}\right)$ and eBC mass concentration. The data coverage ranges between 2 and 6 years (see text and Table 6).

fect mainly for particle diameters below $30 \mathrm{~nm}$, and inconsistencies may occur when older and modern data sets are directly compared. The older data sets are clearly marked on the download page. It is planned that the old data sets will be updated to modern standards.

\section{Preliminary results}

This section provides a brief overview of the data collected in GUAN so far. Figure 4 displays the total particle number concentration (diameter range $20-800 \mathrm{~nm}$ ) and eBC mass concentration at the various GUAN sites as a function of the month of the year, while Table 6 indicates a brief overall statistics of the two parameters based on hourly average values. The data coverage used in this compilation ranged between 2 and 6 years: Annaberg-Buchholz - 3 years (2012-2014); Langen - 3 years (2011-2013); DresdenWinckelmannstr. and Neuglobsow - 4 years (2011-2014); Leipzig-Mitte and Leipzig-West - 5 years (2010-2014); and Augsburg, Bösel (Südoldenburg), Dresden-Nord, Hohenpeißenberg, Leipzig-Eisenbahnstr., Leipzig-Tropos, Melpitz,
Mülheim-Styrum, Schauinsland, Waldhof, and Zugspitze (Schneefernerhaus) - 6 years (2009-2014). The different periods of data coverage reflect, above all, different operation periods at some stations.

Figure 4 illustrates the mean concentrations at the various sites but also their annual course. To facilitate the reading of the figure, the legend has been arranged in descending order of mean concentration. Observations at the roadside are distinct in that they yield an average $N_{[20 ; 800]}$ above $9000 \mathrm{~cm}^{-3}$ most of the year, while urban background and rural observations sites form a continuum of concentrations below that region. Zugspitze (Schneefernerhaus) shows the lowest particle concentrations, due to its altitude above $2500 \mathrm{~m}$.

These findings are also reflected in Table 6, where the sites and values have been sorted according to descending median concentrations of $N_{[20 ; 800]}$. One can clearly see how the stations cluster according to their station type. The concentrations at the stations can therefore be arranged almost completely in the order roadside $>$ urban background $>$ rural $>$ rural (mountain) $>$ Alpine mountain. Overall, the GUAN sites provide a continuum of atmospheric observations over 1 magnitude of median values in total particle number concentration and eBC mass concentration. $N_{[20 ; 800]}$ spans a range between 900 and $9000 \mathrm{~cm}^{-3}$, while eBC ranges between 0.15 and $2.3 \mu \mathrm{g} \mathrm{cm}^{-3}$. One notable exception in the sequence of stations is Bösel (Südoldenburg) — classified as "rural", which seems, however, influenced by sources of particle number that are likely to be found in the adjacent village (cf. location of the site in Fig. 2).

The annual cycle of total particle number concentration yields only a weak annual cycle, whereas this is not the case for the eBC mass concentrations (Fig. 4). For eBC, the monthly maximum concentration occurs between October and March at the urban and rural lowland sites. The summer values (May-September), in contrast, are significantly lower. One explanation is that the atmosphere tends to be less vertically mixed in the winter, leading to the trapping of pollution at the urban and rural lowland sites. Second, eBC emissions are enhanced in wintertime due to the more intensive power and heat generation. In summer, vertical dilution is a common atmospheric phenomenon that will decrease the corresponding mean values. It is worth noting that in summer, the particle mass concentrations of eBC at rural sites are very close to each other, suggesting rather uniform $\mathrm{eBC}$ concentrations in the rural atmosphere.

A more elaborate interpretation of the GUAN data, notably the 2009-2014 section, is currently underway and in preparation for publication in a separate paper.

\section{Conclusions}

The co-operative German Ultrafine Aerosol Network (GUAN) delivers atmospheric particle number size distributions and equivalent black carbon concentrations. Data are 
Table 6. Mean values of total particle number concentration $\left(N_{[20 ; 800]}\right)$ and eBC mass concentration at 17 GUAN sites. The table indicates the number of hourly samples $n$, mean value $\mu$, standard deviation $\sigma$, median ("med"), and the 95th percentile of the hourly statistics ("p95"). Numbers are indicated at a precision of three significant digits. The stations are sorted according the decreasing median of $N_{\text {[20;800] }}$.

\begin{tabular}{|c|c|c|c|c|c|c|c|c|c|c|c|c|c|}
\hline \multirow[t]{2}{*}{ No. } & \multirow[t]{2}{*}{ Site } & \multirow[t]{2}{*}{ Type } & \multirow[t]{2}{*}{ Period } & \multicolumn{5}{|c|}{$N_{[20 ; 800]}$ in $\mathrm{cm}^{-3}$} & \multicolumn{5}{|c|}{$\mathrm{eBC}$ in $\mu \mathrm{g} \mathrm{m}^{-3}$} \\
\hline & & & & $n$ & $\mu_{N}$ & $\sigma_{N}$ & med & p95 & $n$ & $\mu_{\mathrm{eBC}}$ & $\sigma_{\mathrm{eBC}}$ & med & p95 \\
\hline 9 & Leipzig-Mitte & roadside & 2010-2014 & 35400 & 10500 & 6500 & 9000 & 22400 & 37800 & 2.80 & 2.03 & 2.30 & 6.57 \\
\hline 8 & Leipzig-Eisenbahnstr. & roadside & 2009-2014 & 43000 & 9610 & 5600 & 8460 & 20000 & 48400 & 2.15 & 1.65 & 1.71 & 5.28 \\
\hline 4 & Dresden-Nord & roadside & 2009-2014 & 33900 & 9570 & 5440 & 8400 & 19900 & 46900 & 2.48 & 1.61 & 2.10 & 5.56 \\
\hline 13 & Mülheim-Styrum & urban backg. & 2009-2014 & 45100 & 9570 & 5450 & 8330 & 20000 & - & - & - & - & - \\
\hline 7 & Langen & urban backg. & 2011-2013 & 24800 & 6490 & 3840 & 5740 & 13500 & - & - & - & - & - \\
\hline 2 & Augsburg & urban backg. & 2009-2014 & 41900 & 7260 & 5780 & 5630 & 17600 & 42700 & 1.88 & 1.52 & 1.41 & 4.58 \\
\hline 1 & Annaberg-Buchholz & urban backg. & 2012-2014 & 22400 & 6620 & 6450 & 4950 & 16800 & 23300 & 1.65 & 1.75 & 1.12 & 4.99 \\
\hline 10 & Leipzig-Tropos & urban backg. & 2009-2014 & 49200 & 5840 & 4110 & 4840 & 13000 & 51100 & 1.26 & 1.33 & 0.82 & 3.76 \\
\hline 3 & Bösel (Südoldenburg) & rural & 2009-2014 & 46600 & 5380 & 3120 & 4810 & 10900 & 44100 & 0.76 & 0.80 & 0.51 & 2.25 \\
\hline 5 & Dresden-Winckelmannstr. & urban backg. & 2011-2014 & 22400 & 6290 & 6130 & 4710 & 15900 & 23200 & 1.21 & 1.14 & 0.86 & 3.44 \\
\hline 11 & Leipzig-West & urban backg. & 2010-2014 & 28600 & 4960 & 3210 & 4210 & 10600 & 36000 & 1.21 & 1.23 & 0.79 & 3.64 \\
\hline 12 & Melpitz & rural & 2009-2014 & 47400 & 4380 & 3000 & 3710 & 9620 & 51400 & 0.90 & 1.16 & 0.52 & 3.03 \\
\hline 16 & Waldhof & rural & 2009-2014 & 49700 & 3860 & 2350 & 3390 & 8050 & 39000 & 0.60 & 0.68 & 0.39 & 1.92 \\
\hline 14 & Neuglobsow & rural & 2011-2014 & 27000 & 3270 & 1840 & 2940 & 6590 & 41000 & 0.74 & 0.91 & 0.40 & 2.50 \\
\hline 6 & Hohenpeißenberg & rural (mountain) & 2009-2014 & 48800 & 2600 & 1470 & 2360 & 5280 & 52500 & 0.44 & 0.43 & 0.33 & 1.27 \\
\hline 15 & Schauinsland & rural (mountain) & 2009-2014 & 44100 & 1950 & 1430 & 1640 & 4590 & 43000 & 0.32 & 0.36 & 0.22 & 0.96 \\
\hline 17 & Zugspitze (Schneef.) & Alpine mount. & 2013-2014 & 39000 & 1120 & 874 & 886 & 2780 & 46900 & 0.17 & 0.10 & 0.15 & 0.37 \\
\hline
\end{tabular}

transferred to the World Data Center for Aerosols repository EBAS (doi:10.5072/guan) at regular intervals. These continuously measured data are expected to provide the basis for a better scientific understanding of sub- $\mu \mathrm{m}$ aerosol processes in the troposphere, addressing questions related to both human particle exposure and climate-relevant effects. Particle number size distributions down to $5 \mathrm{~nm}$ allow us to study the emission and formation processes of atmospheric ultrafine particles (e.g. Ma and Birmili, 2015). Black carbon, on the other hand, is an essential parameter that is linked to atmospheric particulate light absorption (Bond et al., 2013; Nordmann et al., 2014). Number size distributions of refractory particles $\left(300^{\circ} \mathrm{C}\right)$ represent particle cores that are of likely relevance for health studies and which have been associated with harmful soot particles (Nordmann et al., 2009; Poulain et al., 2014).

The selection of GUAN's measurement sites provides a continuum of exposure situations from roadside sites, urban background sites, and rural background sites to a high Alpine mountain site that spans approximately 1 order in mean concentrations. In association with partner projects, GUAN has implemented a high degree of harmonisation of instrumentation, operating procedures, and data evaluation procedures. The GUAN data have already proved suitable for the validation of atmospheric dispersion and process simulations involving atmospheric aerosols. Examples for their successful use include the validation of a global chemical transport model (Reddington et al., 2011), a regional-scale radiative transfer model (Nordmann et al., 2014; Chen et al., 2016), a street canyon aerosol dynamics model (Toenges-Schuller et al., 2015), and statistical prediction tools for particle number size distributions in rural and urban environments (Mø1gaard et al., 2013; von Bismarck-Osten et al., 2015).
The high standards of the GUAN data make them suitable for use in cross-sectional air quality and health studies, particularly alleviating the lack of health studies using BC and ultrafine particles as exposure variables. In the future, the data set may also serve as an excellent basis for the future discussion of legislative regulation of (ultrafine) particle number and/or BC mass concentrations in ambient air.

\section{Data availability}

This manuscript refers to data from the German Ultrafine Aerosol Network (GUAN) that are stored at the World Data Center for Aerosols EBAS database (Birmili et al., 2015). Data access is possible through the persistent identifier doi:10.5072/guan or by visiting the EBAS user interface directly (http://ebas.nilu.no). When accessing the data set through the persistent identifier (doi:10.5072/guan), visitors will find detailed information on data availability, data acquisition and processing.

Scientific users are free to download, copy, distribute, transmit, and adapt the data sets as long as they adhere to EBAS' data policy, which involves, amongst other things, giving credit to the original authors (cf. Sect. 7). The GUAN data set is not static in that the length of the data records is augmented at regular intervals by fresh, quality-controlled measurements - currently every 6 months (cf. Sect. 7.3). This will lead to a considerably longer, continuous data set in the foreseeable future. 
Appendix A: Correction formula for the aethalometer in Augsburg

At Augsburg, an aethalometer (Type 8100, Thermo Fisher Scientific Inc.) is deployed using a cut-off of $2.5 \mu \mathrm{m}$. Similarly to the MAAP, the Type 8100 aethalometer evaluates the attenuation of transmitted light, although at a different wavelength $(\lambda=880 \mathrm{~nm})$ and using a different mass absorption cross section $\left(16.6 \mathrm{~m}^{2} \mathrm{~g}^{-1}\right)$. To validate the aethalometer's performance, we compared the instrument in Augsburg to a MAAP instrument (Birmili et al., 2010a) during 1 month (9 September-8 October 2008). The intercomparison suggested that the aethalometer values are biased by a value around $+0.3 \mu \mathrm{g} \mathrm{m}^{-3}$ at the zero end, while the mean concentrations during the period matched fairly precisely (MAAP:

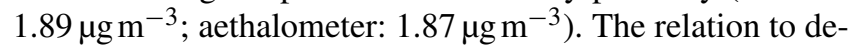
termine standardised (i.e. MAAP-based) black carbon concentrations from the aethalometer is as follows:

$\mathrm{BC}_{\mathrm{MAAP}}=1.111 \cdot \mathrm{BC}_{\mathrm{aeth}}-0.18$

(A1)

For aethalometer concentrations below $1.36 \mu \mathrm{g} \mathrm{m}^{-3}$, a squared fit represents the data more accurately:

$\mathrm{BC}_{\mathrm{MAAP}}=-0.033 \cdot \mathrm{BC}_{\mathrm{aeth}}^{2}+1.335 \cdot \mathrm{BC}_{\mathrm{aeth}}-0.43$.

Both fits show a high measure of determination $\left(R^{2}\right)$ of 0.96 . 


\section{The Supplement related to this article is available online at doi:10.5194/essd-8-355-2016-supplement.}

Acknowledgements. The establishment of GUAN was made possible by the German Federal Environment Ministry (BMU) grants F\&E 370343200 (German title: "Erfassung der Zahl feiner und ultrafeiner Partikel in der Außenluft"), 2008-2010, and F\&E 371143232 (German title: "Trendanalysen gesundheitsgefährdender Fein- und Ultrafeinstaubfraktionen unter Nutzung der im German Ultrafine Aerosol Network (GUAN) ermittelten Immissionsdaten durch Fortführung und Interpretation der Messreihen"), 2012-2014. We acknowledge additional funding within the infrastructure projects EUSAAR (European Supersites for Atmospheric Aerosol Research; EU FP6 contract RII3-CT-2006-026140), and ACTRIS (Aerosols, Clouds, and Trace gases Research InfraStructure Network; EU FP7 grant 262254). WCCAP was funded by the German Federal Environment Agency (UBA) grant FKZ 35101086 (The World Calibration Centre for Aerosol Physics within WMO-GAW), 2012-2014. We acknowledge funding by the LfULG grants UFP 2011 (German title: "Qualitätssicherung der Messung ultrafeiner Partikel in Außenluft 2011") and UFP 2012 ("Aufwandsreduzierung in der Qualitätskontrolle der Messung ultrafeiner Partikel in der Außenluft im Luftgütemessnetz Sachsen"). Measurements at Annaberg-Buchholz were supported by the EU-Ziel3 project UltraSchwarz (German title: "Ultrafeinstaub und Gesundheit im Erzgebirgskreis und Region Usti”), grant 100083657. Measurements at Dresden-Winckelmannstrasse were co-funded by the European Regional Development Fund Financing Programme Central Europe, grant No. 3 CE288P (UFIREG). Measurements in Augsburg were financed by the Helmholtz Zentrum Munich and partly by UFIREG (see above). IUTA e.V. acknowledges funding by the State Agency for Nature, Environment, and Consumer Protection North Rhine-Westphalia (LANUV), grant title: "Untersuchung ultrafeiner Partikel zur räumlichen und zeitlichen Verteilung im Ruhrgebiet". Individual credits for TROPOS personnel: Thomas Tuch and Achim Grüner (TROPOS station Melpitz), Stephan Nordmann (MAAP measurements), and Johanna Rehn (map generation). We thank Horst-Günther Kath (State Dept. for Environmental and Agricultural Operations in Saxony, Betriebsgesellschaft für Umwelt und Landwirtschaft - BfUL), Andreas Hainsch and Dirk Haase (Labour Inspectorate of Lower Saxony, Staatliches Gewerbeaufsichtsamt Hildesheim - GAA), and Dieter Gladtke (LANUV), who made the GUAN measurements possible at the observations sites of their air quality networks.

Edited by: A. Kokhanovsky

Reviewed by: two anonymous referees

\section{References}

Asmi, A., Wiedensohler, A., Laj, P., Fjaeraa, A.-M., Sellegri, K., Birmili, W., Weingartner, E., Baltensperger, U., Zdimal, V., Zikova, N., Putaud, J.-P., Marinoni, A., Tunved, P., Hansson, H.C., Fiebig, M., Kivekäs, N., Lihavainen, H., Asmi, E., Ulevicius, V., Aalto, P. P., Swietlicki, E., Kristensson, A., Mihalopoulos, N., Kalivitis, N., Kalapov, I., Kiss, G., de Leeuw, G., Henzing, B., Harrison, R. M., Beddows, D., O’Dowd, C., Jennings, S. G., Flentje, H., Weinhold, K., Meinhardt, F., Ries, L., and Kulmala, M.: Number size distributions and seasonality of submicron particles in Europe 2008-2009, Atmos. Chem. Phys., 11, 5505-5538, doi:10.5194/acp-11-5505-2011, 2011.

Baltensperger, U. and Prévôt, A. S. H.: Chemical analysis of atmospheric aerosols, Anal. Bioanal. Chem., 390, 277-280, doi:10.1007/s00216-007-1687-z, 2008.

Beuck, H., Quass, U., Klemm, O., and Kuhlbusch, T. A. J.: Assessment of sea salt and mineral dust contributions to $\mathrm{PM}_{10}$ in NW Germany using tracer models and positive matrix factorization, Atmos. Environ., 45, 5813-5821, doi:10.1016/j.atmosenv.2011.07.010, 2011.

Birmili, W. and Wiedensohler, A.: New particle formation in the continental boundary laxer: meteorological and gas phase parameter influence, Geophys. Res. Lett., 27, 3325-3328, doi:10.1029/1999GL011221, 2000.

Birmili, W., Stratmann, F., and Wiedensohler, A.: Design of a DMA-based size spectrometer for a large particle size range and stable operation, J. Aerosol Sci., 30, 549-553, doi:10.1016/S0021-8502(98)00047-0, 1999.

Birmili, W., Berresheim, H., Plass-Dülmer, C., Elste, T., Gilge, S., Wiedensohler, A., and Uhrner, U.: The Hohenpeissenberg aerosol formation experiment (HAFEX): a long-term study including size-resolved aerosol, $\mathrm{H}_{2} \mathrm{SO}_{4}, \mathrm{OH}$, and monoterpenes measurements, Atmos. Chem. Phys., 3, 361-376, doi:10.5194/acp-3-361-2003, 2003.

Birmili, W., Schepanski, K., Ansmann, A., Spindler, G., Tegen, I., Wehner, B., Nowak, A., Reimer, E., Mattis, I., Müller, K., Brüggemann, E., Gnauk, T., Herrmann, H., Wiedensohler, A., Althausen, D., Schladitz, A., Tuch, T., and Löschau, G.: A case of extreme particulate matter concentrations over Central Europe caused by dust emitted over the southern Ukraine, Atmos. Chem. Phys., 8, 997-1016, doi:10.5194/acp-8-997-2008, 2008.

Birmili, W., Weinhold, K., Nordmann, S., Wiedensohler, A., Spindler, G., Müller, K., Herrmann, H., Gnauk, T., Pitz, M., Cyrys, J., Flentje, H., Nickel, C., Kuhlbusch, T. A. J., Löschau, G., Haase, D., Meinhardt, F., Schwerin, A., Ries, L., and Wirtz, K.: Atmospheric aerosol measurements in the German Ultrafine Aerosol Network (GUAN): Part 1 - soot and particle number size distributions, Gefahrst. Reinhalt. L., 69, 137-145, 2009a.

Birmili, W., Ries, L., Sohmer, R., Anastou, A., Sonntag, A., König, K., and Levin, I.: Fine and ultrafine aerosol particles at the GAW station Schneefernerhaus/Zugspitze, Gefahrst. Reinhalt. L., 69, 31-35, 2009b.

Birmili, W., Heinke, K., Pitz, M., Matschullat, J., Wiedensohler, A., Cyrys, J., Wichmann, H.-E., and Peters, A.: Particle number size distributions in urban air before and after volatilisation, Atmos. Chem. Phys., 10, 4643-4660, doi:10.5194/acp-10-4643-2010, 2010a. 
Birmili, W., Göbel, T., Sonntag, A., Ries, L., Sohmer, R., Gilge, S., Levin, I., and Stohl, A.: A case of transatlantic aerosol transport detected at the Schneefernerhaus Observatory $(2650 \mathrm{~m})$ on the northern edge of the Alps, Meteorol. Z., 19, 591-600, doi:10.1127/0941-2948/2010/0465, 2010b.

Birmili, W., Tomsche, L., Sonntag, A., Opelt, C., Weinhold, K., Nordmann, S., and Schmidt, W.: Variability of aerosol particles in the urban atmosphere of Dresden (Germany): effects of spatial scale and particle size, Meteorol. Z., 22, 195-211, doi:10.1127/0941-2948/2013/0395, 2013.

Birmili, W., Weinhold, K., Merkel, M., Rasch, F., Sonntag, A., Wiedensohler, A., Bastian, S., Schladitz, A., Löschau, G., Cyrys, J., Pitz, M., Gu, J., Kusch, T., Flentje, H., Quass, U., Kaminski, H., Kuhlbusch, T. A. J., Meinhardt, F., Schwerin, A., Bath, O., Ries, L., and Wirtz, K.: The German Ultrafine Aerosol Network (GUAN): Atmospheric particle number size distributions and equivalent black carbon mass concentrations, 20092014, doi:10.5072/guan, 2015.

Bohren, C. F. and Huffman, D. R.: Absorption and Scattering of Light by Small Particles, John Wiley \& Sons, doi:10.1002/9783527618156, 544 pp., Weinheim, Germany, 1998.

Bond, T. C., Doherty, S. J., Fahey, D. W., Forster, P. M., Berntsen, T., DeAngelo, B. J., Flanner, M. G., Ghan, S., Kärcher, B., Koch, D., Kinne, S., Kondo, Y., Quinn, P. K., Sarofim, M. C., Schultz, M. G., Schulz, M., Venkataraman, C., Zhang, H., Zhang, S., Bellouin, N., Guttikunda, S. K., Hopke, P. H., Jacobson, M. Z., Kaiser, J. W., Klimont, Z., Lohmann, U., Schwarz, J. P., Shindell, D., Storelvmo, T., Warren, S. G., and Zender, C. S.: Bounding the role of black carbon in the climate system: a scientific assessment, J. Geophys. Res.-Atmos., 118, 5380-5552, doi:10.1002/jgrd.50171, 2013.

Chen, Y., Cheng, Y. F., Nordmann, S., Birmili, W., Denier van der Gon, H. A. C., Ma, N., Wolke, R., Wehner, B., Sun, J., Spindler, G., Mu, Q., Pöschl, U., Su, H., and Wiedensohler, A.: Evaluation of the size segregation of elemental carbon (EC) emission in Europe: influence on the simulation of EC long-range transport, Atmos. Chem. Phys., 16, 1823-1835, doi:10.5194/acp-16-1823-2016, 2016.

Costabile, F., Birmili, W., Klose, S., Tuch, T., Wehner, B., Wiedensohler, A., Franck, U., König, K., and Sonntag, A.: Spatiotemporal variability and principal components of the particle number size distribution in an urban atmosphere, Atmos. Chem. Phys., 9, 3163-3195, doi:10.5194/acp-9-3163-2009, 2009.

Dockery, D. W. and Pope, C. A.: Acute respiratory effects of particulate air pollution, Annu. Rev. Publ. Health, 15, 107-132, doi:10.1146/annurev.pu.15.050194.000543, 1994.

Dockery, D. W. and Stone, P. H.: Cardiovascular risks from fine particulate air pollution, New Engl. J. Med., 356, 511-513, doi:10.1056/NEJMe068274, 2007.

Ehn, M., Petäjä, T., Birmili, W., Junninen, H., Aalto, P., and Kulmala, M.: Non-volatile residuals of newly formed atmospheric particles in the boreal forest, Atmos. Chem. Phys., 7, 677-684, doi:10.5194/acp-7-677-2007, 2007.

Engler, C., Rose, D., Wehner, B., Wiedensohler, A., Brüggemann, E., Gnauk, T., Spindler, G., Tuch, T., and Birmili, W.: Size distributions of non-volatile particle residuals $\left(D_{p}<800 \mathrm{~nm}\right)$ at a rural site in Germany and relation to air mass origin, At- mos. Chem. Phys., 7, 5785-5802, doi:10.5194/acp-7-5785-2007, 2007.

Engler, C., Birmili, W., Spindler, G., and Wiedensohler, A.: Analysis of exceedances in the daily $\mathrm{PM}_{10}$ mass concentration $\left(50 \mu \mathrm{g} \mathrm{m}^{-3}\right)$ at a roadside station in Leipzig, Germany, Atmos. Chem. Phys., 12, 10107-10123, doi:10.5194/acp-1210107-2012, 2012.

Franck, U., Odeh, S., Wiedensohler, A., Wehner, B., and Herbarth, O.: The effect of particle size on cardiovascular disorders - the smaller the worse, Sci. Total Environ., 409, 42174221, doi:10.1016/j.scitotenv.2011.05.049, 2011.

Gerwig, H., Pecher, W., and Wirtz, K.: Ursache für maximale Partikeloberflächenkonzentrationen in Langen bei Frankfurt, oral presentation at: 49. Messtechnisches Kolloquium, Dresden, 2628 May 2014.

Gnauk, T., Müller, K., Brüggemann, E., Birmili, W., Weinhold, K., van Pinxteren, D., Löschau, G., Spindler, G., and Herrmann, H.: A study to discriminate local, urban and regional source contributions to the particulate matter concentrations in the city of Dresden, Germany, J. Atmos. Chem., 68, 199-231, doi:10.1007/s10874-012-9216-7, 2012.

Größ, J., Birmili, W., Hamed, A., Sonntag, A., Wiedensohler, A., Spindler, G., Maninnen, H. E., Nieminen, T., Kulmala, M., Hõrrak, U., and Plass-Dülmer, C.: Evolution of gaseous precursors and meteorological parameters during new particle formation events in the Central European boundary layer, Atmos. Chem. Phys. Discuss., 15, 2305-2353, doi:10.5194/acpd-152305-2015, 2015.

Gu, J., Pitz, M., Breitner, S., Birmili, W., von Klot, S., Schneider, A., Soentgen, J., Reller, A., Peters, A., and Cyrys, J.: Selection of key ambient particulate variables for epidemiological studies - applying cluster and heatmap analyses as tools for data reduction, Sci. Total Environ., 435/436, 541-550, doi:10.1016/j.scitotenv.2012.07.040, 2012.

Hänel, G.: The properties of atmospheric aerosol particles as functions of the relative humidity at thermodynamic equilibrium with the surrounding moist air, Adv. Geophys., 19, 74-188, doi:10.1016/S0065-2687(08)60142-9, 1976.

Haywood, J. and Boucher, O.: Estimates of the direct and indirect radiative forcing due to tropospheric aerosols: a review, Rev. Geophys., 38, 513-543, doi:10.1029/1999RG000078, 2000.

HEI Review Panel on Ultrafine Particles: Understanding the Health Effects of Ambient Ultrafine Particles. HEI Perspectives 3, Health Effects Institute, Boston, MA, January 2013.

Janssen, N. A. H., Gerlofs-Nijland, M. E., Lanki, T., Salonen, R. O., Cassee, F., Hoek, G., Fischer, P., Brunekreef, B., and Krzyzanowski, M.: Health effects of black carbon, World Health Organisation (WHO), Regional Offce for Europe, Copenhagen, Denmark, 86 pp., 2012.

Jones, A. M., Harrison, R. M., Barratt, B., and Fuller, G.: A large reduction in airborne particle number concentrations at the time of the introduction of "sulphur free" diesel and the London Low Emission Zone, Atmos. Environ., 50, 129-138, doi:10.1016/j.atmosenv.2011.12.050, 2012.

Kumar, P., Morawska, L., Birmili, W., Paasonen, P., Hu, M., Kulmala, M., Harrison, R. M., Norford, L., and Britter, R.: Ultrafine particles in cities, Environ. Int., 66, 1-10, doi:10.1016/j.envint.2014.01.013, 2014. 
Laj, P., Klausen, J., Bilde, M., Plass-Duelmer, C., Pappalardo, G., Clerbaux, C., Baltensperger, U., Hjorth, J., Simpson, D., Reimann, S., Coheur, P.-F., Richter, A., De Maziere, M., Rudich, Y., McFiggans, G., Torseth, K., Wiedensohler, A., Morin, S., Schulz, M., Allan, J. D., Attie, J.-L., Barnes, I., Birmili, W., Cammas, J. P., Dommen, J., Dorn, H.-P., Fowler, D., Fuzzi, S., Glasius, M., Granier, C., Hermann, M., Isaksen, I. S. A., Kinne, S., Koren, I., Madonna, F., Maione, M., Massling, A., Moehler, O., Mona, L., Monks, P. S., Müller, D., Müller, T., Orphal, J., Peuch, V.-H., Stratmann, F., Tanre, D., Tyndall, D., Abo Riziq, A., Van Roozendael, M., Villani, P., Wehner, B., Wex, H., and Zardini, A. A.: Measuring atmospheric composition change, Atmos. Environ., 43, 5351-5414, doi:10.1016/j.atmosenv.2009.08.020, 2009.

Lelieveld, J., Evans, J. S., Fnais, M., Giannadaki, D., and Pozzer, A.: The contribution of outdoor air pollution sources to premature mortality on a global scale, Nature, 525, 367-371, doi:10.1038/nature15371, 2015.

Lohmann, U. and Feichter, J.: Global indirect aerosol effects: a review, Atmos. Chem. Phys., 5, 715-737, doi:10.5194/acp-5-7152005, 2005.

Löschau, G., Wiedensohler, A., Wehner, B., Birmili, W., and Gerwig, H.: Measurement of the number concentration of ultrafine particles in ambient air in an air quality monitoring network Part 2: Results of a traffic-orientated long term measurement, Gefahrst. Reinhalt. L., 70, 183-187, 2010.

Löschau, G., Wiedensohler, A., Birmili, W., Rasch, F., Spindler, G., Müller, K., Wolf, U., Hausmann, A., and Herrmann, H.: The low-emission zone in Leipzig, part 1: initial state (Umweltzone Leipzig, Teil 1: Ausgangsbeurteilung), Landesamt für Umwelt, Landwirtschaft und Geologie, 83 pp., Dresden, Germany, 2012 (in German).

Löschau, G., Wiedensohler, A., Birmili, W., Rasch, F., Spindler, G., Müller, K., Wolf, U., Hausmann, A., Böttger, M., Anhalt, M., and Herrmann, H.: The low-emission zone in Leipzig, part 2: state of air quality in 2011 (Umweltzone Leipzig, Teil 2: Immissionssituation 2011), Landesamt für Umwelt, Landwirtschaft und Geologie, 89 pp., Dresden, Germany, 2013 (in German).

Löschau, G., Wiedensohler, A., Birmili, W., Rasch, F., Spindler, G., Müller, K., Wolf, U., Hausmann, A., Böttger, M., Anhalt, M., Dietz, V., Herrmann, H., and Böhme, U.: The low-emission zone in Leipzig, part 3: state of air quality 2010-2013 (Umweltzone Leipzig, Teil 3: Immissionssituation 2010-2013), Landesamt für Umwelt, Landwirtschaft und Geologie, 73 pp., Dresden, Germany, 2014 (in German).

Löschau, G., Wiedensohler, A., Birmili, W., Rasch, F., Spindler, G., Müller, K., Wolf, U., Hausmann, A., Böttger, M., Bastian, S., Anhalt, M., Dietz, V., Herrmann, H., and Böhme, U.: The lowemission zone in Leipzig, part 4: state of air quality 2010-2014 (Umweltzone Leipzig, Teil 4: Immissionssituation 2010-2014), Landesamt für Umwelt, Landwirtschaft und Geologie, 75 pp., Dresden, Germany, 2015 (in German).

Ma, N. and Birmili, W.: Estimating the contribution of photochemical particle formation to ultrafine particle number averages in an urban atmosphere, Sci. Total Environ., 512/513, 154-166, doi:10.1016/j.scitotenv.2015.01.009, 2015.

Ma, N., Birmili, W., Müller, T., Tuch, T., Cheng, Y. F., Xu, W. Y., Zhao, C. S., and Wiedensohler, A.: Tropospheric aerosol scattering and absorption over central Europe: a closure study for the dry particle state, Atmos. Chem. Phys., 14, 6241-6259, doi:10.5194/acp-14-6241-2014, 2014.

McMurry, P. H.: A review of atmospheric aerosol measurements, Atmos. Environ., 34, 1959-1999, doi:10.1016/S13522310(99)00455-0, 2000.

Mølgaard, B., Birmili, W., Clifford, S., Massling, A., Eleftheriadis, K., Norman, M., Vratolis, S., Wehner, B., Corander, J., Hämeri, K., and Hussein, T.: Evaluation of a statistical forecast model for size-fractionated urban particle number concentrations using data from five European cities, J. Aerosol Sci., 66, 96-110, doi:10.1016/j.jaerosci.2013.08.012, 2013.

Müller, T., Schladitz, A., Massling, A., Kaaden, N., Kandler, K., and Wiedensohler, A.: Spectral absorption coefficients and imaginary parts of refractive indices of Saharan dust during SAMUM-1, Tellus B, 61, 79-95, doi:10.3402/tellusb.v61i1.16816, 2009.

Müller, T., Henzing, J. S., de Leeuw, G., Wiedensohler, A., Alastuey, A., Angelov, H., Bizjak, M., Collaud Coen, M., Engström, J. E., Gruening, C., Hillamo, R., Hoffer, A., Imre, K., Ivanow, P., Jennings, G., Sun, J. Y., Kalivitis, N., Karlsson, H., Komppula, M., Laj, P., Li, S.-M., Lunder, C., Marinoni, A., Martins dos Santos, S., Moerman, M., Nowak, A., Ogren, J. A., Petzold, A., Pichon, J. M., Rodriquez, S., Sharma, S., Sheridan, P. J., Teinilä, K., Tuch, T., Viana, M., Virkkula, A., Weingartner, E., Wilhelm, R., and Wang, Y. Q.: Characterization and intercomparison of aerosol absorption photometers: result of two intercomparison workshops, Atmos. Meas. Tech., 4, 245-268, doi:10.5194/amt-4-245-2011, 2011.

Nordmann, S., Birmili, W., Weinhold, K., Wiedensohler, A., Mertes, S., Müller, K., Gnauk, T., Herrmann, H., Pitz, M., Cyrys, J., Flentje, H., Ries, L., and Wirtz, K.: Atmospheric aerosol measurements in the German Ultrafine Aerosol Network (GUAN) - Part 2: Comparison of measurements techniques for graphitic, light-absorbing, and elemental carbon, and the nonvolatile particle volume under field conditions, Gefahrst. Reinhalt. L., 69, 469-474, 2009.

Nordmann, S., Birmili, W., Weinhold, K., Müller, K., Spindler, G., and Wiedensohler, A.: Measurements of the mass absorption cross section of atmospheric soot particles using Raman spectroscopy, J. Geophys. Res.-Atmos., 118, 12075-12085, doi:10.1002/2013JD020021, 2013.

Nordmann, S., Cheng, Y. F., Carmichael, G. R., Yu, M., Denier van der Gon, H. A. C., Zhang, Q., Saide, P. E., Pöschl, U., $\mathrm{Su}, \mathrm{H}$., Birmili, W., and Wiedensohler, A.: Atmospheric black carbon and warming effects influenced by the source and absorption enhancement in central Europe, Atmos. Chem. Phys., 14, 12683-12699, doi:10.5194/acp-14-12683-2014, 2014.

Ibald-Mulli, A., Wichmann, H.-E., Kreyling, W., and Peters, A.: Epidemiological evidence on health effects of ultrafine particles, J. Aerosol Med., 15, 189-201, doi:10.1089/089426802320282310, 2002.

Petzold, A. and Schönlinner, M.: Multi-angle absorption photometry - a new method for the measurement of aerosol light absorption and atmospheric black carbon, J. Aerosol Sci., 35, 421-441, doi:10.1016/j.jaerosci.2003.09.005, 2004.

Petzold, A., Ogren, J. A., Fiebig, M., Laj, P., Li, S.-M., Baltensperger, U., Holzer-Popp, T., Kinne, S., Pappalardo, G., Sugimoto, N., Wehrli, C., Wiedensohler, A., and Zhang, X.-Y.: Recommendations for reporting "black carbon" measurements, At- 
mos. Chem. Phys., 13, 8365-8379, doi:10.5194/acp-13-83652013, 2013.

Pfeifer, S., Birmili, W., Schladitz, A., Müller, T., Nowak, A., and Wiedensohler, A.: A fast and easy-to-implement inversion algorithm for mobility particle size spectrometers considering particle number size distribution information outside of the detection range, Atmos. Meas. Tech., 7, 95-105, doi:10.5194/amt-795-2014, 2014.

Pitz, M., Birmili, W., Schmid, O., Peters, A., Wichmann, H.-E., and Cyrys, J.: Quality control and quality assurance for particle size distribution measurements at an urban monitoring station in Augsburg, Germany, J. Environ. Monitor., 10, 1017-1024, doi:10.1039/b807264g, 2008.

Pope, C. A., Burnett, R. T., Thurston, G. D., Thun, M. J., Calle, E. E., Krewski, D., and Godleski, J. J.: Cardiovascular mortality and long-term exposure to particulate air pollution, Circulation, 109, 71-77, doi:10.1161/01.CIR.0000108927.80044.7F, 2004.

Pöschl, U.: Atmospheric aerosols: composition, transformation, climate and health effects, Angew. Chem. Int. Edit., 44, 7520-7540, doi:10.1002/anie.200501122, 2005.

Poulain, L., Birmili, W., Canonaco, F., Crippa, M., Wu, Z. J., Nordmann, S., Spindler, G., Prévôt, A. S. H., Wiedensohler, A., and Herrmann, H.: Chemical mass balance of $300^{\circ} \mathrm{C}$ non-volatile particles at the tropospheric research site Melpitz, Germany, Atmos. Chem. Phys., 14, 10145-10162, doi:10.5194/acp-1410145-2014, 2014.

Quass, U., Kuhlbusch, T., Koch, M., Fissan, H., Schmidt, K.-G., Bruckmann, P., Pfeffer, U., Gladtke, D., and Zang, T.: Identification of source groups for fine dust (in German, Identifizierung von Quellgruppen für die Feinstaubfraktion), Public report to the Ministry of the Environment of North Rhine-Westphalia, Germany, 2004.

Ramanathan, V., Crutzen, P. J., Lelieveld, J., Mitra, A. P., Althausen, D., Anderson, J., Andreae, M. O., Cantrell, W., Cass, G. R., Chung, C. E., Clarke, A. D., Coakley, J. A., Collins, W. D., Conant, W. C., Dulac, F., Heintzenberg, J., Heymsfield, A. J., Holben, B., Howell, S., Hudson, J., Jayaraman, A., Kiehl, J. T., Krishnamurti, T. N., Lubin, D., McFarquhar, G., Novakov, T., Ogren, J. A., Podgorny, I. A., Prather, K., Priestley, K., Prospero, J. M., Quinn, P. K., Rajeev, K., Rasch, P., Rupert, S., Sadourny, R., Satheesh, S. K., Shaw, G. E., Sheridan, P., and Valero, F. P. J.: Indian Ocean Experiment: an integrated analysis of the climate forcing and effects of the great Indo-Asian haze, J. Geophys. Res., 106, 28371-28398, doi:10.1029/2001JD900133, 2001.

Rasch, F., Birmili, W., Weinhold, K., Nordmann, S., Sonntag, A., Spindler, G., Herrmann, H., Wiedensohler, A., and Löschau, G.: Significant reduction of ambient black carbon and particle number in Leipzig as a result of the low emission zone, Gefahrst. Reinhalt. L., 73, 483-489, 2013.

Reddington, C. L., Carslaw, K. S., Spracklen, D. V., Frontoso, M. G., Collins, L., Merikanto, J., Minikin, A., Hamburger, T., Coe, H., Kulmala, M., Aalto, P., Flentje, H., PlassDülmer, C., Birmili, W., Wiedensohler, A., Wehner, B., Tuch, T., Sonntag, A., O’Dowd, C. D., Jennings, S. G., Dupuy, R., Baltensperger, U., Weingartner, E., Hansson, H.-C., Tunved, P., Laj, P., Sellegri, K., Boulon, J., Putaud, J.-P., Gruening, C., Swietlicki, E., Roldin, P., Henzing, J. S., Moerman, M., Mihalopoulos, N., Kouvarakis, G., Ždímal, V., Zíková, N., Marinoni, A., Bonasoni, P., and Duchi, R.: Primary versus secondary contribu- tions to particle number concentrations in the European boundary layer, Atmos. Chem. Phys., 11, 12007-12036, doi:10.5194/acp11-12007-2011, 2011.

Rückerl, R., Schneider, A., Breitner, S., Cyrys, J., and Peters, A.: Health effects of particulate air pollution: a review of epidemiological evidence, Inhal. Toxicol., 23, 555-592, doi:10.3109/08958378.2011.593587, 2011.

Schäfer, K., Thomas, W., Peters, A., Ries, L., Obleitner, F., Schnelle-Kreis, J., Birmili, W., Diemer, J., Fricke, W., Junkermann, W., Pitz, M., Emeis, S., Forkel, R., Suppan, P., Flentje, H., Gilge, S., Wichmann, H. E., Meinhardt, F., Zimmermann, R., Weinhold, K., Soentgen, J., Münkel, C., Freuer, C., and Cyrys, J.: Influences of the 2010 Eyjafjallajökull volcanic plume on air quality in the northern Alpine region, Atmos. Chem. Phys., 11, 8555-8575, doi:10.5194/acp-11-8555-2011, 2011.

Schmidt, M., Graul, R., Sartorius, H., and Levin, I.: The Schauinsland $\mathrm{CO}_{2}$ record: 30 years of continental observations and their implications for the variability of the European $\mathrm{CO}_{2}$ budget, J. Geophys. Res., 108, 4619, doi:10.1029/2002JD003085, 2003.

Schladitz, A., Merkel, M., Bastian, S., Birmili, W., Weinhold, K., Löschau, G., and Wiedensohler, A.: A concept of an automated function control for ambient aerosol measurements using mobility particle size spectrometers, Atmos. Meas. Tech., 7, 10651073, doi:10.5194/amt-7-1065-2014, 2014.

Schladitz, A., Lenícek, J., Beneš, I., Kovác, M., Skorkovský, J., Soukup, A., Jandlová, J., Poulain, L., Plachá, H., Löschau, G., and Wiedensohler, A.: Air quality in the German-Czech border region: a focus on harmful fractions of PM and ultrafine particles, Atmos. Environ., 122, 236-249, doi:10.1016/j.atmosenv.2015.09.044, 2015.

Spindler, G., Brüggemann, E., Gnauk, T., Grüner, A., Müller, K., and Herrmann, H.: A four-year size-segregated characterization study of particles $\mathrm{PM}_{10}, \mathrm{PM}_{2.5}$ and $\mathrm{PM}_{1}$ depending on air mass origin at Melpitz, Atmos. Environ., 44, 164-173, doi:10.1016/j.atmosenv.2009.10.015, 2010.

Sun, H., Biedermann, L., and Bond, T.: Color of brown carbon: a model for ultraviolet and visible light absorption by organic carbon aerosol, Geophys. Res. Lett., 34, L17813, doi:10.1029/2007GL029797, 2007.

Swietlicki, E., Hansson, H.-C., Hämeri, K., Svenningsson, B., Massling, A. McFiggans, G., McMurry, P. H., Petäjä, T., Tunved, P., Gysel, M., Topping, D., Weingartner, E., Baltensperger, U., Rissler, J., Wiedensohler, A., and Kulmala, M.: Hygroscopic properties of submicrometer atmospheric aerosol particles measured with H-TDMA instruments in various environments - a review, Tellus, 60B, 432-469, doi:10.1111/j.16000889.2008.00350.x, 2008.

Toenges-Schuller, N., Schneider, C., Niederau, A., Vogt, R., and Birmili, W.: Modelling particle number concentrations in a typical street canyon in Germany and analysis of future trends, Atmos. Environ., 111, 127-135, doi:10.1016/j.atmosenv.2015.04.006, 2015.

Tørseth, K., Aas, W., Breivik, K., Fjæraa, A. M., Fiebig, M., Hjellbrekke, A. G., Lund Myhre, C., Solberg, S., and Yttri, K. E.: Introduction to the European Monitoring and Evaluation Programme (EMEP) and observed atmospheric composition change during 1972-2009, Atmos. Chem. Phys., 12, 5447-5481, doi:10.5194/acp-12-5447-2012, 2012. 
Tunved, P., Hansson, H.-C., Kulmala, M., Aalto, P., Viisanen, Y., Karlsson, H., Kristensson, A., Swietlicki, E., Dal Maso, M., Ström, J., and Komppula, M.: One year boundary layer aerosol size distribution data from five nordic background stations, Atmos. Chem. Phys., 3, 2183-2205, doi:10.5194/acp-3-2183-2003, 2003.

UBA: Das Luftmessnetz des Umweltbundesamtes: Langzeitmessungen, Prozessverständnis und Wirkungen ferntransportierter Luftverunreinigungen, Tech. Rep., edited by: Schleyer, R., Bieber, E., and Wallasch, M., Umweltbundesamt (UBA), Dessau-Rosslau, 112 pp., 2013.

Voigtländer, J., Tuch, T., Birmili, W., and Wiedensohler, A.: Correlation between traffic density and particle size distribution in a street canyon and the dependence on wind direction, Atmos. Chem. Phys., 6, 4275-4286, doi:10.5194/acp-6-4275-2006, 2006.

von Bismarck-Osten, C., Birmili, W., Ketzel, M., Massling, A., Petäjä, T., and Weber, S.: Characterization of parameters influencing the spatio-temporal variability of urban aerosol particle number size distributions in four European cities, Atmos. Environ., 77, 415-429, doi:10.1016/j.atmosenv.2013.05.029, 2013.

von Bismarck-Osten, C., Birmili, W., Ketzel, M., and Weber, S.: Statistical modelling of aerosol particle number size distributions in urban and rural environments - a multi-site study, Urban Climate, 11, 51-66, doi:10.1016/j.uclim.2014.11.004, 2015.

Weigelt, A., Temme, C., Bieber, E., Schwerin, A., Schuetze, M., Ebinghaus, R., and Kock, H. H.: Measurements of atmospheric mercury species at a German rural background site from 2009 to 2011 - methods and results, Environ. Chem., 10, 102-110, doi:10.1071/EN12107, 2013.
Wehner, B., Philippin, S., Wiedensohler, A., and Haudek, A.: Design and calibration of an improved thermodenuder to study the volatility fraction of aerosol particles, J. Aerosol Sci., 33, 10871093, doi:10.1016/S0021-8502(02)00056-3, 2002.

Wiedensohler, A., Birmili, W., Nowak, A., Sonntag, A., Weinhold, K., Merkel, M., Wehner, B., Tuch, T., Pfeifer, S., Fiebig, M., Fjäraa, A. M., Asmi, E., Sellegri, K., Depuy, R., Venzac, H., Villani, P., Laj, P., Aalto, P., Ogren, J. A., Swietlicki, E., Williams, P., Roldin, P., Quincey, P., Hüglin, C., FierzSchmidhauser, R., Gysel, M., Weingartner, E., Riccobono, F., Santos, S., Grüning, C., Faloon, K., Beddows, D., Harrison, R., Monahan, C., Jennings, S. G., O’Dowd, C. D., Marinoni, A., Horn, H.-G., Keck, L., Jiang, J., Scheckman, J., McMurry, P. H., Deng, Z., Zhao, C. S., Moerman, M., Henzing, B., de Leeuw, G., Löschau, G., and Bastian, S.: Mobility particle size spectrometers: harmonization of technical standards and data structure to facilitate high quality long-term observations of atmospheric particle number size distributions, Atmos. Meas. Tech., 5, 657-685, doi:10.5194/amt-5-657-2012, 2012.

Zieger, P., Fierz-Schmidhauser, R., Weingartner, E., and Baltensperger, U.: Effects of relative humidity on aerosol light scattering: results from different European sites, Atmos. Chem. Phys., 13, 10609-10631, doi:10.5194/acp-13-10609-2013, 2013.

Zieger, P., Fierz-Schmidhauser, R., Poulain, L., Müller, T., Birmili, W., Spindler, G., Wiedensohler, A., Baltensperger, U., and Weingartner, E.: Influence of water uptake on the aerosol particle light scattering coefficients of the Central European aerosol, Tellus B, 66, 22716, doi:10.3402/tellusb.v66.22716, 2014. 